\title{
Worsening urban ozone pollution in China from 2013 to 2017 - Part 2: The effects of emission changes and implications for multi-pollutant control
}

\author{
Yiming Liu and Tao Wang \\ Department of Civil and Environmental Engineering, The Hong Kong Polytechnic University, Hong Kong, 999077, China
}

Correspondence: Tao Wang (cetwang@polyu.edu.hk)

Received: 20 January 2020 - Discussion started: 3 February 2020

Revised: 14 April 2020 - Accepted: 27 April 2020 - Published: 3 June 2020

\begin{abstract}
The Chinese government launched the Air Pollution Prevention and Control Action Plan in 2013, and various stringent measures have since been implemented, which have resulted in significant decreases in emissions and ambient concentrations of primary pollutants such as $\mathrm{SO}_{2}, \mathrm{NO}_{x}$, and particulate matter (PM). However, surface ozone $\left(\mathrm{O}_{3}\right)$ concentrations have still been increasing in urban areas across the country. In a previous analysis, we examined in detail the roles of meteorological variation during 2013-2017 in the summertime surface $\mathrm{O}_{3}$ trend in various regions of China. In this study, we evaluated the effect of changes in multi-pollutant emissions from anthropogenic activities on $\mathrm{O}_{3}$ levels during the same period by using an up-to-date regional chemical transport model (WRF-CMAQ) driven by an interannual anthropogenic emission inventory. The Community Multiscale Air Quality (CMAQ) model was improved with regard to heterogeneous reactions of reactive gases on aerosol surfaces, which led to better model performance in reproducing the ambient concentrations of those gases. The model simulations showed that the maximum daily $8 \mathrm{~h}$ average (MDA8) $\mathrm{O}_{3}$ mixing ratio in urban areas increased by 0.46 ppbv per year $\left(\mathrm{ppbv} \mathrm{a}^{-1}\right)(p=0.001)$ from 2013 to 2017. In contrast, a slight decrease in MDA8 $\mathrm{O}_{3}$ by $0.17 \mathrm{ppbva}^{-1}(p=0.005)$ in rural areas was predicted, mainly attributable to the $\mathrm{NO}_{x}$ emission reduction. The effects of changes in individual pollutant emissions on $\mathrm{O}_{3}$ were also simulated. The reduction of $\mathrm{NO}_{x}$ emission increased the $\mathrm{O}_{3}$ levels in urban areas due to the nonlinear $\mathrm{NO}_{x}$ and volatile organic compound (VOC) chemistry and decreasing aerosol effects; the slight increase in VOC emissions enhanced the $\mathrm{O}_{3}$ levels; the reduction of PM emissions increased the $\mathrm{O}_{3}$ levels by enhancing the photolysis rates
\end{abstract}

and reducing the loss of reactive gases on aerosol surfaces; and the reduction of $\mathrm{SO}_{2}$ emissions resulted in a drastic decrease in sulfate concentrations, which increased $\mathrm{O}_{3}$ through aerosol effects. In contrast to the unfavorable effect of the above changes in pollutant emissions on efforts to reduce surface $\mathrm{O}_{3}$, the reduction of $\mathrm{CO}$ emissions did help to decrease the $\mathrm{O}_{3}$ level in recent years. The dominant cause of increasing $\mathrm{O}_{3}$ due to changes in anthropogenic emissions varied geographically. In Beijing, $\mathrm{NO}_{x}$ and $\mathrm{PM}$ emission reductions were the two largest causes of the $\mathrm{O}_{3}$ increase; in Shanghai, the reduction of $\mathrm{NO}_{x}$ and increase in VOC emissions were the two major causes; in Guangzhou, $\mathrm{NO}_{x}$ reduction was the primary cause; in Chengdu, the $\mathrm{PM}$ and $\mathrm{SO}_{2}$ emission decreases contributed most to the $\mathrm{O}_{3}$ increase. Regarding the effects of decreasing concentrations of aerosols, the drop in heterogeneous uptake of reactive gases - mainly $\mathrm{HO}_{2}$ and $\mathrm{O}_{3}$ - was found to be more important than the increase in photolysis rates. The adverse effect of the reductions of $\mathrm{NO}_{x}, \mathrm{SO}_{2}$, and $\mathrm{PM}$ emissions on $\mathrm{O}_{3}$ abatement in Beijing, Shanghai, Guangzhou, and Chengdu would have been avoided if the anthropogenic VOCs emission had been reduced by $24 \%$, $23 \%, 20 \%$, and $16 \%$, respectively, from 2013 to 2017 . Our analysis revealed that the $\mathrm{NO}_{x}$ reduction in recent years has helped to contain the total $\mathrm{O}_{3}$ production in China. However, to reduce $\mathrm{O}_{3}$ levels in major urban and industrial areas, VOC emission controls should be added to the current $\mathrm{NO}_{x}-\mathrm{SO}_{2}$ PM policy. 


\section{Introduction}

China has experienced severe haze pollution due to high concentrations of particulate matter (PM) in the past decade (e.g., Guo et al., 2014; Huang et al., 2014). To alleviate this air-quality problem, the Chinese government launched the Air Pollution Prevention and Control Action Plan in 2013 and has since implemented various emission-control measures (Zhang et al., 2019). Anthropogenic emissions of sulfur dioxide $\left(\mathrm{SO}_{2}\right)$, nitrogen oxides $\left(\mathrm{NO}_{x}\right)$, carbon monoxide (CO), and $\mathrm{PM}_{2.5}$ (PM with an aerodynamic diameter less than $2.5 \mu \mathrm{m}$ ) in China were reduced by $59 \%, 21 \%, 23 \%$, and $33 \%$ from 2013 to 2017, respectively, while the emission of volatile organic compounds (VOCs) increased slightly (Zheng et al., 2018). As a result, ambient concentrations of $\mathrm{SO}_{2}, \mathrm{NO}_{2}, \mathrm{CO}, \mathrm{PM}_{2.5}$, and $\mathrm{PM}_{10}$ (PM with an aerodynamic diameter less than $10 \mu \mathrm{m}$ ) have declined, according to data from national environmental monitoring stations (http: //www.mee.gov.cn, last access: 18 January 2020; Fig. S1 in the Supplement). However, surface ozone $\left(\mathrm{O}_{3}\right)$ concentrations in urban and surrounding areas increased from 2013 to 2017 (Lu et al., 2018). It is of critical importance to evaluate the effects of the existing control policies on atmospheric $\mathrm{O}_{3}$ and refine these, if necessary, to improve overall air quality.

Ground-level $\mathrm{O}_{3}$ is produced by chemical reactions involving $\mathrm{NO}_{x}, \mathrm{CO}$, and VOCs in the presence of sunlight. The key step in $\mathrm{O}_{3}$ formation is the oxidation of nitric oxide (NO) by hydroperoxyl $\left(\mathrm{HO}_{2}\right)$ and alkylperoxyl $\left(\mathrm{RO}_{2}\right)$ to form $\mathrm{NO}_{2}$, with subsequent photolysis of $\mathrm{NO}_{2}$. It is well known that the relationship between $\mathrm{O}_{3}$ and its precursors is nonlinear and that $\mathrm{NO}_{x}$ can either suppress or increase $\mathrm{O}_{3}$ formation depending on its abundance relative to VOCs (and CO) (e.g., Atkinson, 2000; T. Wang et al., 2017). A large body of literature has established that $\mathrm{O}_{3}$ formation in urban centers is generally VOCs limited; that is, reducing VOC emissions leads to a decrease in $\mathrm{O}_{3}$ concentrations, but reducing $\mathrm{NO}_{x}$ emissions has the opposite result; in contrast, $\mathrm{O}_{3}$ formation above rural areas is typically in the $\mathrm{NO}_{x}$-limited or transitional regime, in which reducing $\mathrm{NO}_{x}$ emissions results in decreased $\mathrm{O}_{3}$ (NRC, 1991; Atkinson, 2000; T. Wang et al., 2017). Any process that perturbs $\mathrm{HO}_{2}$ and $\mathrm{RO}_{2}$ radicals will also affect $\mathrm{O}_{3}$ production (e.g., J. Li et al., 2018). Therefore, elucidating the chemical drivers of $\mathrm{O}_{3}$ changes requires understanding the abundance and proportions of $\mathrm{O}_{3}$ precursors and the radicals involved in $\mathrm{O}_{3}$ formation. Aerosols in the atmosphere can affect $\mathrm{O}_{3}$ concentrations via altering the solar actinic flux, which photolyzes gases to initiate oxidation ( $\mathrm{Li}$ et al., 2011; Xing et al., 2017) and via heterogeneous reactions of reactive gases on aerosol surfaces (J. Li et al., 2018; Stadtler et al., 2018; Lou et al., 2014).

Several studies have attempted to uncover the chemical drivers of the recent $\mathrm{O}_{3}$ increase in China. Using a regional chemical transport model (WRF-CMAQ), P. F. Wang et al. (2019) derived the variation of maximum daily $8 \mathrm{~h}$ average (MDA8) $\mathrm{O}_{3}$ due to emission changes during 2013-2015 by subtracting the simulated changes due to meteorological variations from the total observed changes. They found that the increase in $\mathrm{O}_{3}$ concentrations in 2014-2015 relative to 2013 was mainly due to the emission changes, and they speculated that the decrease in $\mathrm{PM}_{2.5}$ concentrations and the reduction of $\mathrm{NO}_{x}$ emission in VOC-limited regions could be the causes. In their study, however, the effects of emission changes during the study period were not explicitly simulated with interannual emissions. Li et al. (2019) utilized a global model (GEOS-Chem) to simulate the MDA8 $\mathrm{O}_{3}$ in 2013 and 2017 and conducted sensitivity experiments for the effects of changes in $\mathrm{PM}_{2.5}$ concentrations and anthropogenic emissions of $\mathrm{O}_{3}$ precursors $\left(\mathrm{NO}_{x}\right.$ and VOCs). Their results indicated that the drastic decrease in the $\mathrm{PM}_{2.5}$ concentrations $(\sim 40 \%)$ during the period, which reduced the uptake of $\mathrm{HO}_{2}$ on aerosol surfaces, was the main reason for the $\mathrm{O}_{3}$ increase in the North China Plain (NCP). N. Wang et al. (2019) simulated the effect of $\mathrm{NO}_{x}$ emission reduction during 2012-2016 with the WRF-CMAQ model in eastern China, which indicated increasing surface $\mathrm{O}_{3}$ in urban areas due to the reduction of $\mathrm{NO}_{x}$ emissions. Yu et al. (2019) applied the Kolmogorov-Zurbenko filtering technique to the observed MDA8 $\mathrm{O}_{3}$ during 2013-2017 in the Yangtze River Delta region and concluded that the changes in $\mathrm{O}_{3}$ precursor emissions contributed $76.7 \%$ to the $\mathrm{O}_{3}$ increase, compared with $22 \%$ due to the decrease in $\mathrm{PM}_{2.5}$ concentration.

We have been further investigating the meteorological and chemical driver(s) of the increasing summer surface $\mathrm{O}_{3}$ in urban areas of China during 2013-2017 using an improved regional chemical transport model (WRF-CMAQ) driven by interannual meteorological data and anthropogenic emission inventories. The role of meteorological variation and total emission changes, the effect of changes in individual meteorological factors, and the impact of changes in long-range transport of $\mathrm{O}_{3}$ and its precursors from outside the modeling domain are discussed in a companion paper (Part 1; Liu and Wang, 2020). The goal of the present work is to quantify (1) the effect of the changes in anthropogenic emissions of individual pollutants $\left(\mathrm{NO}_{x}\right.$, VOCs, $\mathrm{CO}, \mathrm{PM}, \mathrm{SO}_{2}$, and $\left.\mathrm{NH}_{3}\right)$ on urban $\mathrm{O}_{3}$, which has not been addressed in the aforementioned studies but is important for further development of mitigation policy and (2) the effects of changes in aerosol concentrations on $\mathrm{O}_{3}$ using a regional model with up-to-date radical sources and heterogeneous reactions. The improved model should give a more realistic account of gas-particle interactions crucial to $\mathrm{O}_{3}$ formation, compared with its earlier version. In Sect. 2, we briefly introduce the model system and experiment settings; Sect. 3 first compares the simulated reactive gases that are subject to significant heterogeneous reactions with the observations reported in the literature. We then quantify the simulated trends of MDA8 $\mathrm{O}_{3}$ in urban and rural areas during 2013-2017. We further investigate the response of MDA8 $\mathrm{O}_{3}$ to the changes in individual pollutant emissions from anthropogenic activities from 2013 to 2017. We then examine the effect of aerosols on the $\mathrm{O}_{3}$ changes 
by altering the photolysis rates and heterogeneous reactions. Lastly, we conduct numerical sensitivity experiments to calculate the magnitude of VOCs emission reductions needed to overcome the adverse effect of other pollutant reductions on the goal of $\mathrm{O}_{3}$ mitigation. Section 4 gives the conclusions.

\section{Methods}

\subsection{Model settings and emission inputs}

The CMAQ model (Community Multiscale Air Quality model, version 5.2.1) driven by the Weather Research and Forecasting (WRF) model and the interannual Multiresolution Emission Inventory for China (MEIC; http://www. meicmodel.org, last access: 18 January 2020) was applied to conduct the simulations in this study. The model settings and emission inputs are described in the companion paper (Liu and Wang, 2020). The CMAQ model is an offline chemical transport model (Byun and Schere, 2006) that does not consider the effect of pollutants on meteorology but applies an in-line method (Binkowski et al., 2007) that uses the aerosol and $\mathrm{O}_{3}$ concentrations predicted within a simulation to calculate the solar radiation and photolysis rates. As a result, the model takes into consideration the effect of aerosols on $\mathrm{O}_{3}$ formation via altering the photolysis rates.

\subsection{Updating heterogeneous reactions}

The heterogeneous reactions in the original CMAQ model (version 5.2.1) include only the absorptions of $\mathrm{NO}_{2}, \mathrm{NO}_{3}$, and $\mathrm{N}_{2} \mathrm{O}_{5}$ on aerosol surfaces. To faithfully reproduce the effect of aerosols on $\mathrm{O}_{3}$ via scavenging gaseous pollutants, we updated the heterogeneous reaction rate of $\mathrm{NO}_{2}$ and $\mathrm{NO}_{3}$ on the aerosol surface and incorporated additional heterogeneous reactions of gases into the CMAQ model, namely those of $\mathrm{HO}_{2}, \mathrm{O}_{3}, \mathrm{OH}$, and $\mathrm{H}_{2} \mathrm{O}_{2}$ (refer to Table $\mathrm{S} 2$ in the companion paper (Liu and Wang, 2020) for the detailed heterogeneous reactions in the original and updated CMAQ models). The uptake coefficients $(\gamma)$ of gases are the key parameters of heterogeneous reactions, but they vary according to factors such as aerosol water content and aerosol composition. In this study, we selected the "best guess" uptake coefficients for the gases, which have been widely used in chemical transport models in previous studies.

The uptake coefficient of $\mathrm{N}_{2} \mathrm{O}_{5}$ in the original CMAQ model was incorporated by Sarwar et al. (2012), based on the parameterization developed by Bertram and Thornton (2009) that considered its dependence on particle liquid water, particulate nitrate, and chloride.

The heterogeneous reaction rate of $\mathrm{NO}_{2}$ in the original CMAQ model was suggested by Kurtenbach et al. (2001), based on the measurements at a relative humidity of $50 \%$ under dark conditions. Field and laboratory studies found that the rate not only depends on the relative humidity (Qin et al., 2009; Stutz et al., 2004) but also on sunlight intensity (Ndour et al., 2008; Stemmler et al., 2007). Fu et al. (2019) developed a new parameterization for the $\mathrm{NO}_{2}$ heterogeneous reaction rate that considered both these factors, which has improved the simulation of the reaction product, i.e., nitrous acid (HONO). This parameterization was adopted in the updated CMAQ model.

Several laboratory studies have shown that the measured $\gamma \mathrm{NO}_{3}$ ranges from $10^{-4}$ to $10^{-2}$ (Rudich et al., 1996; Exner et al., 1992; Moise et al., 2002). In the original CMAQ model, $10^{-4}$ was adopted as the value for $\gamma \mathrm{NO}_{3}$ (Mao et al., 2013). A higher value $\left(10^{-3}\right)$ was recommended by Jacob (2000) and was subsequently widely adopted in chemical transport models to investigate the effect of heterogeneous reactions on $\mathrm{O}_{3}$ concentrations (Stadtler et al., 2018; Lou et al., 2014). This value was adopted in the updated CMAQ model.

The uptake coefficients of $\mathrm{HO}_{2}$ vary widely, depending on the transition metal ions contained in aerosols (George et al., 2013; Huijnen et al., 2014). The heterogeneous reaction of $\mathrm{HO}_{2}$ can produce either $\mathrm{H}_{2} \mathrm{O}_{2}$ or $\mathrm{H}_{2} \mathrm{O}$, depending on the particulate compounds in the aqueous phase. Li et al. (2019) conducted sensitivity experiments for the products of this reaction using the GEOS-Chem model, finding little dependence on the reaction products when assessing the effect of aerosol on $\mathrm{O}_{3}$ concentrations. Here, we let the heterogeneous reaction of $\mathrm{HO}_{2}$ produce only $\mathrm{H}_{2} \mathrm{O}_{2}$, and adopt 0.2 for $\gamma_{\mathrm{HO}_{2}}$, as recommended by Jacob (2000).

We used the value of 0.1 for the uptake coefficient of $\mathrm{OH}$, based on the laboratory studies of DeMore et al. (1997). This value was also adopted by Zhang and Carmichael (1999) and Zhu et al. (2010) to explore heterogeneous reactions in a chemical transport model.

Previous laboratory and field studies of the heterogeneous reaction of $\mathrm{O}_{3}$ have given a wide range of $\gamma_{\mathrm{O}_{3}}$ : from $10^{-6}$ to $10^{-4}$ on dust (Michel et al., 2002, 2003; Hanisch and Crowley, 2003), up to $10^{-4}$ on sodium chloride aerosol (Abbatt and Waschewsky, 1998), and from $10^{-5}$ to $10^{-3}$ on soot particles (Longfellow et al., 2000). Most previous modeling studies adopted $1 \times 10^{-5}$ (Liao et al., 2004; Liao and Seinfeld, 2005; Pozzoli et al., 2008), while one recommended a lower value $\left(3 \times 10^{-6}\right)$ for dust particles (Bauer et al., 2004). We applied $10^{-5}$ to the uptake of $\mathrm{O}_{3}$ on all the aerosols in our simulation.

DeMore et al. (1997) reported that the uptake coefficient of $\mathrm{H}_{2} \mathrm{O}_{2}$ on sulfuric acid and water surfaces ranged from $8 \times 10^{-4}$ to 0.18 . De Reus et al. (2005) found that using accommodation coefficients of 0.2 and $2 \times 10^{-3}$ for $\mathrm{HO}_{2}$ and $\mathrm{H}_{2} \mathrm{O}_{2}$, respectively, ensured agreement between simulated and observed values, under the assumption that $\mathrm{H}_{2} \mathrm{O}_{2}$ was produced in the heterogeneous reaction of $\mathrm{HO}_{2}$. Thus, $2 \times 10^{-3}$ was adopted for the uptake coefficient of $\mathrm{H}_{2} \mathrm{O}_{2}$ in this study.

The companion paper (Part 1; Liu and Wang, 2020) presented validation results of the updated CMAQ model against the observations of $\mathrm{SO}_{2}, \mathrm{NO}_{2}, \mathrm{CO}, \mathrm{O}_{3}$, and $\mathrm{PM}_{2.5}$ from national environmental monitoring stations. In this study, we 
used the updated and original CMAQ models to simulate the concentrations of gases lost or produced on aerosol surfaces for the summer of 2013 and compared the simulated results with the observations reported in the literature (Table S1 in the Supplement).

\subsection{Experiment settings}

We applied the updated WRF-CMAQ model to conduct simulations for the summer months (June, July, and August) from 2013 to 2017 with anthropogenic emissions. The shipping emissions were kept unchanged in the 5-year simulation, due to a lack of data for recent years. In Part 1 of our work (Liu and Wang, 2020), we showed the effect of changes in total anthropogenic emissions on $\mathrm{O}_{3}$ changes by comparing the $\mathrm{O}_{3}$ levels in 2013 simulated using anthropogenic emissions from different years. In this study, three additional sets of modeling experiments were established. The first was designed to quantify the responses of $\mathrm{O}_{3}$ to changes in individual pollutant emissions from 2013 to 2017, with the simulation in 2013 being regarded as the baseline experiment. The anthropogenic emissions of $\mathrm{NO}_{x}, \mathrm{VOCs}, \mathrm{SO}_{2}, \mathrm{CO}, \mathrm{NH}_{3}, \mathrm{PM}$ (comprising $\mathrm{PM}_{10}, \mathrm{PM}_{2.5}$, and its components), black carbon (BC), organic carbon (OC), and combined $\mathrm{NO}_{x}$ and VOCs in 2013 were changed individually to those for 2017 in each sensitivity experiment (total number of experiments is 10), and the results were compared with those in the baseline experiment (Table S2). The second set of experiments was designed to investigate the effect of changes in aerosols on $\mathrm{O}_{3}$ levels via altering the photolysis rates and heterogeneous reactions (Table S3). The individual effects of aerosols were deleted in each sensitivity experiment, and the results were compared with those in the baseline simulation. The corresponding differences showed the effects of aerosols on $\mathrm{O}_{3}$ in 2013 in terms of photolysis rates or with respect to each heterogeneous reaction. A similar method was applied to the simulation of 2013 but with the 2017 anthropogenic emissions, and the difference was the effect of aerosols on the $\mathrm{O}_{3}$ levels when the anthropogenic emissions of 2017 were applied in 2013. Finally, by comparing the results before and after the change in emissions from 2013 to 2017, the responses of $\mathrm{O}_{3}$ to changes in aerosols via altering the photolysis rates and each heterogeneous reaction were quantified. Nineteen sensitivity experiments were performed. The third set of experiments was designed to calculate the magnitude that the VOC emissions in 2017 would have had to be reduced by from 2013 to overcome the adverse effect of the changes in other pollutant emissions on $\mathrm{O}_{3}$ reduction during this period. Based on the simulation of 2013 incorporating the 2017 anthropogenic emissions of all pollutants except VOCs, the VOC emissions were reduced by $10 \%, 20 \%, 30 \%, 40 \%$, and $50 \%$ in the sensitivity runs and the results were compared with those in the baseline experiment (Table S4). By comparing the response of the $2013 \mathrm{O}_{3}$ level to various VOC emission reductions, the required reduction of VOC emissions was quantified.

\section{Results}

\subsection{Comparison of the simulated and observed reactive gases}

The simulated mixing ratios of reactive gases that are subject to significant heterogeneous reactions were compared with the observed values for the gases $\mathrm{O}_{3}, \mathrm{NO}_{2}, \mathrm{NO}_{3}, \mathrm{~N}_{2} \mathrm{O}_{5}$, $\mathrm{HONO}, \mathrm{ClNO}_{2}, \mathrm{HO}_{2}, \mathrm{OH}$, and $\mathrm{H}_{2} \mathrm{O}_{2}$ (Table S1). Except for $\mathrm{O}_{3}$ and $\mathrm{NO}_{2}$, which are measured by the regular national air monitoring network, the other gases were measured only in research-focused field campaigns. We compiled literaturereported summer concentrations of these gases for various years and compared these with the model-simulated values for 2013.

The uptake of $\mathrm{NO}_{2}$ on wet aerosol surfaces can produce HONO in the atmosphere, which is an important source of $\mathrm{OH}$ radicals via photolysis. After the update of the CMAQ model, the predicted average $\mathrm{NO}_{2}$ mixing ratio in China decreased from 19.2 to $16.6 \mathrm{ppbv}$, which came close to the observed value (15.1 ppbv). As a product of $\mathrm{NO}_{2}$ uptake, the HONO mixing ratios increased significantly and approached the observed values in Beijing (J. Q. Wang et al., 2017) and Guangzhou (Qin et al., 2009; X. Li et al., 2012). The decrease in $\mathrm{NO}_{2}$ and increase in $\mathrm{HONO}$ were attributed to the increase in heterogeneous reaction rates of $\mathrm{NO}_{2}$ due to the effects of relative humidity and sunlight intensity in the updated CMAQ model (Fu et al., 2019). Table S1 also presents the observed HONO mixing ratios at two coastal sites in Hong Kong (Z. Y. Li et al., 2018; Xu et al., 2015), but their levels were substantially underpredicted because capturing such coastal characteristics is challenging for the model, due to its low horizontal resolution $(36 \mathrm{~km})$.

The simulated $\mathrm{NO}_{3}$ mixing ratio decreased slightly $\left(\sim 1\right.$ pptv) due to the decrease in $\mathrm{NO}_{2}$ and $\mathrm{O}_{3}$ mixing ratios and the increase in $\gamma \mathrm{NO}_{3}$ (from $10^{-4}$ to $10^{-3}$ ). This decrease in $\mathrm{NO}_{3}$ value was much smaller than the differences between the simulated and observed values in Shanghai (Wang et al., 2013) and Guangzhou (S. W. Li et al., 2012). Nevertheless, the simulated $\mathrm{NO}_{3}$ value moved closer to the observed value in Shanghai (Wang et al., 2013) after the heterogeneous reactions in the model were updated.

The parameterization of $\gamma_{\mathrm{N}_{2} \mathrm{O}_{5}}$ remains unchanged in the revised model. However, the decrease in $\mathrm{NO}_{2}$ and $\mathrm{O}_{3}$ levels resulted in a decrease in $\mathrm{N}_{2} \mathrm{O}_{5}$ and thus a decrease in $\mathrm{ClNO}_{2}$. The simulated maximum $\mathrm{N}_{2} \mathrm{O}_{5}$ mixing ratio at the Wangdu site decreased by $\sim 50 \%$ and thus agreed much better with the observed value (Tham et al., 2016). The simulated maximum $\mathrm{ClNO}_{2}$ mixing ratio decreased slightly, by a margin much smaller than the biases between the simulation and observation. Table $\mathrm{S} 1$ presents the observed $\mathrm{N}_{2} \mathrm{O}_{5}$ and $\mathrm{ClNO}_{2}$ 
values at a high-altitude site on Mount Tai (Z. Wang et al., 2017) and a coastal site in Hong Kong (Yan et al., 2019; Tham et al., 2014). Large differences between simulations and observations were found due to the complex terrains at these two sites, which are difficult for our model to simulate.

The CMAQ model predicted the mixing ratios of $\mathrm{HO}_{2}$ and $\mathrm{OH}$ radicals to be slightly lower after the incorporation of their heterogeneous reactions. The changes were small, probably due to the scavenging effects of aerosols being counteracted by the increase in radical sources generated by HONO photolysis. The measured value for $\mathrm{HO}_{2}$ contains an uncorrected contribution from $\mathrm{RO}_{2}$ (Fuchs et al., 2011), which could explain in part the underestimation of $\mathrm{HO}_{2}$ that occurred when using the updated and original models. For $\mathrm{OH}$ radicals, the mixing ratios simulated by both the original and updated models were comparable with the observed value in Wangdu (Tan et al., 2017), Beijing (Lu et al., 2013), and Guangzhou (Lu et al., 2012). The slight decrease in the $\mathrm{OH}$ mixing ratio after the update helped bring the simulation closer to the observations.

In the original CMAQ model, the MDA8 $\mathrm{O}_{3}$ mixing ratio was overestimated by $11.4 \mathrm{ppbv}$. The bias was reduced to $6.8 \mathrm{ppbv}$ with the updated heterogeneous reactions. In addition to the greater uptake of $\mathrm{O}_{3}$ on aerosol surfaces, the updated model also includes other heterogeneous gas-aerosol reactions, weakening the atmospheric oxidation capacity and thus inhibiting $\mathrm{O}_{3}$ formation.

The $\mathrm{H}_{2} \mathrm{O}_{2}$ mixing ratio decreased substantially from $\sim 0.8$ to $\sim 0.2 \mathrm{ppbv}$, and the simulated value agreed well with the values recorded in Wangdu (Wang et al., 2016) and Beijing (Qin et al., 2018; Liang et al., 2013) after updating the model. Our results suggest that the chemical transport models are likely to substantially overestimate the $\mathrm{H}_{2} \mathrm{O}_{2}$ concentration if they do not include the sink of $\mathrm{H}_{2} \mathrm{O}_{2}$ on aerosol surfaces.

In summary, after updating the heterogeneous reactions in the CMAQ model, the simulations agreed better with the observations, especially for $\mathrm{NO}_{2}, \mathrm{HONO}, \mathrm{O}_{3}$, and $\mathrm{H}_{2} \mathrm{O}_{2}$.

\subsection{Variations in the urban and rural $\mathrm{O}_{3}$}

As most of the 493 air-quality monitoring sites established in 2013 are located in urban areas (refer to Fig. S1 in Part 1, Liu and Wang, 2020), the data from these stations mainly reflect the $\mathrm{O}_{3}$ concentration changes in urban areas. The model simulations for the summer months from 2013 to 2017 over China give a comprehensive picture of the $\mathrm{O}_{3}$ variations over the entire land areas of the country. Our previous analysis based on model simulations revealed that different trends in $\mathrm{O}_{3}$ concentrations existed in urban and rural areas (Liu and Wang, 2020). In this study, we further quantified the $\mathrm{O}_{3}$ trends in urban and rural areas over China using the nighttime light data from the Visible Infrared Imaging Radiometer Suite (VIIRS) Day/Night Band (DNB) (Fig. S2). We allocated the nighttime light data to the CMAQ modeling domain and averaged the values in each modeling grid cell. An urban

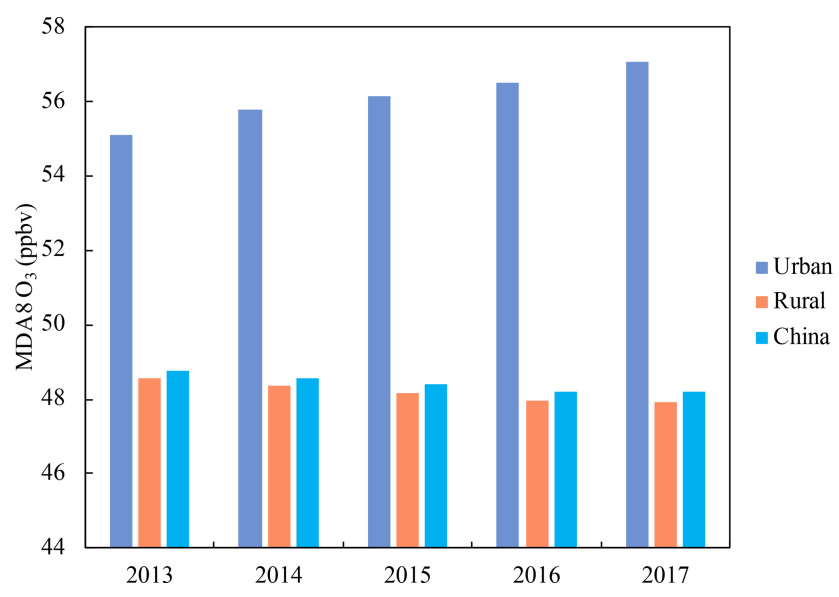

Figure 1. Trends of simulated MDA8 $\mathrm{O}_{3}$ mixing ratios averaged in urban and rural areas and all land areas of China in summer (JuneAugust) from 2013 to 2017. See Fig. S3 for the locations of urban and rural areas.

area (or rural area) was regarded as a grid point with an averaged light value $\geq 2 \mathrm{nW} \mathrm{cm}^{-2} \mathrm{sr}^{-1}$ (or $<2 \mathrm{nW} \mathrm{cm}^{-2} \mathrm{sr}^{-1}$ ). Figure $\mathrm{S} 3$ shows the spatial distribution of the urban and rural areas in China. The rates of changes in the MDA8 $\mathrm{O}_{3}$ mixing ratios in urban and rural areas from 2013 to 2017 were then quantified based on the simulation results (Fig. 1). The model predicted that the MDA8 $\mathrm{O}_{3}$ mixing ratio in urban areas increased at a rate of $0.46 \mathrm{ppbv}$ per year $\left(\mathrm{ppbv} \mathrm{a}^{-1}\right)$ $(p=0.001)$. This simulated increase $(\sim 2$ ppbv from 2013 to 2017 ) in the nightlight-classified urban areas is much lower than the average increase observed at 493 sites in 74 cities ( $\sim 9$ ppbv, Fig. S1d). The discrepancy can be explained as follows. The urban areas determined using the nightlight data are not exactly the same as those 493 sites and cover some rural areas (with decreasing ozone) and additional small townships (Fig. S3). When we matched the modeled locations to the 493 observation sites, the model captured $57 \%$ of the rate of increase of MDA8 $\mathrm{O}_{3}$ averaged at those sites (see Fig. S3 in Part 1, Liu and Wang, 2020). Part 1 also showed a large variability of meteorological impacts on $\mathrm{O}_{3}$ in different regions (e.g., Beijing, Shanghai, Guangzhou, and Chengdu), and the simulated overall urban $\mathrm{O}_{3}$ trend with a high confidence level ( $p=0.001)$ suggests that this regional variability in meteorological impact can be "averaged out", leading to a clearer urban $\mathrm{O}_{3}$ trend driven by emission changes.

The simulated MDA $8 \mathrm{O}_{3}$ mixing ratio in rural areas decreased at a rate of $-0.17 \mathrm{ppbva}^{-1}(p=0.005)$, which is supported by the recently reported rural ozone trends in China. T. Wang et al. (2019) revealed no significant change in $\mathrm{O}_{3}$ levels observed at a coastal site (Hok Tsui) in South China in the outflow of air mass from eastern China during 2007-2018. More recently, Xu et al. (2020) reported decreasing $\mathrm{O}_{3}$ mixing ratios from 2013 to 2016 at two rural sites in Beijing-Tianjin-Hebei (BTH) (Shangduanzi) and 
Yangtze River Delta (YRD) (Linan). Overall, the MDA8 $\mathrm{O}_{3}$ mixing ratio in China exhibited a slightly decreasing trend $\left(-0.15\right.$ ppbva $\left.^{-1}, p=0.006\right)$ due to the decrease in a large rural area, which suggested that the ozone concentration has leveled off in recent years.

\subsection{Response of $\mathrm{O}_{3}$ to changes in multi-pollutant emissions}

Figure 2 presents the spatial distribution of changes in individual pollutant emissions in 2017 relative to 2013 (http: //www.meicmodel.org, last access: 18 January 2020). Significant reductions in anthropogenic emissions of $\mathrm{NO}_{x}, \mathrm{CO}$, $\mathrm{SO}_{2}, \mathrm{NH}_{3}, \mathrm{PM}_{10}, \mathrm{PM}_{2.5}, \mathrm{BC}$, and $\mathrm{OC}$ were found in eastern China, while the emissions in western China decreased slightly and even increased in some areas. $\mathrm{NH}_{3}$ emission, which is primarily from agriculture (Fig. S4e), generally decreased across eastern China but increased in large areas in Neimenggu (Inner Mongolia Autonomous Region) and northwestern China and some scattered areas in eastern China. VOC emissions, which have not been subject to effective control measures, increased at scattered points (mostly industrial sites) over eastern China, except for Shandong province, where VOC emissions decreased across the region. In summary, the emissions of $\mathrm{NO}_{x}, \mathrm{CO}, \mathrm{SO}_{2}, \mathrm{PM}_{10}$, $\mathrm{PM}_{2.5}, \mathrm{BC}$, and $\mathrm{OC}$ over mainland China were reduced by $21 \%, 24 \%, 61 \%, 38 \%, 33 \%, 29 \%$, and $34 \%$ in summer from 2013 to 2017, respectively (Fig. S4). In contrast, $\mathrm{NH}_{3}$ emissions only decreased by $4 \%$, and VOC emissions increased by $5 \%$ during the same period.

Figure 3 shows the spatial distribution of the effect of changes in these pollutant emissions on the MDA8 $\mathrm{O}_{3}$ levels over China between 2013 and 2017. The average changes in $\mathrm{O}_{3}$ mixing ratios in urban and rural areas (see Fig. S3 for their locations) are shown in Fig. 4a and b, respectively. The decrease in $\mathrm{NO}_{x}$ emissions caused an increase in $\mathrm{O}_{3}$ mixing ratios in urban and industrial hot spots but a decrease in $\mathrm{O}_{3}$ concentrations across a large swathe of rural areas (Fig. 3a). Quantitatively, the MDA8 $\mathrm{O}_{3}$ mixing ratio increased by $0.30 \mathrm{ppbv}$ in urban areas and decreased by $1.08 \mathrm{ppbv}$ in rural areas, due to the $\mathrm{NO}_{x}$ emission reductions (Fig. 4a and b). In view of the small effects of changes in other pollutant emissions on rural $\mathrm{O}_{3}$ mixing ratios (Fig. 4b), the decreasing trend of $\mathrm{O}_{3}$ levels from 2013 to 2017 in rural areas was mainly ascribed to the reduction of $\mathrm{NO}_{x}$ emissions, consistent with the fact that $\mathrm{O}_{3}$ formation in rural areas in China is generally limited by $\mathrm{NO}_{x}$ (e.g., Xing et al., 2011; $\mathrm{T}$. Wang et al., 2017). The increase in $\mathrm{O}_{3}$ levels in urban areas due to $\mathrm{NO}_{x}$ reductions can be explained by two factors. First, most urban areas are in the VOCs-limited regime, where the reduction of $\mathrm{NO}_{x}$ emissions reduces the $\mathrm{NO}$ titration effect on $\mathrm{O}_{3}$, resulting in increased $\mathrm{O}_{3}$ concentrations. Second, the decrease in $\mathrm{NO}_{x}$ emissions can reduce the $\mathrm{NO}_{3}^{-}$concentration and increase $\mathrm{O}_{3}$ via weakening the aerosol effects.
In the simulation of VOCs emission changes, the spatial distribution of the $\mathrm{O}_{3}$ levels closely tracked the changes in VOC emissions (Fig. 3b). Specifically, the increase in VOCs emission caused an increase in the MDA8 $\mathrm{O}_{3}$ mixing ratios across eastern China, except for Shandong province, where $\mathrm{O}_{3}$ levels decreased due to the substantial reduction of VOC emissions from the transportation sector according to the MEIC emission inventory (http://www.meicmodel.org, last access: 18 January 2020). The simulation predicted an increase of $0.41 \mathrm{ppbv}$ in the $\mathrm{MDA} 8 \mathrm{O}_{3}$ mixing ratios from 2013 to 2017 due to the increase in VOC emissions in urban areas (Fig. 4a). When changes in both the $\mathrm{NO}_{x}$ and VOC emissions were simulated, it was the changes in $\mathrm{NO}_{x}$ emissions that primarily contributed to the changes in $\mathrm{O}_{3}$ mixing ratio (Fig. 3c). In the simulation of changing $\mathrm{CO}$ emissions, the reduction of $\mathrm{CO}$ emissions reduced the $\mathrm{O}_{3}$ level across China (Fig. 3d). A particularly large decrease in the $\mathrm{O}_{3}$ mixing ratio was found in the NCP region, where both the $\mathrm{CO}$ emissions and their corresponding reduction were large. The $\mathrm{CO}$ emission reductions led to a decrease of $0.41 \mathrm{ppbv}$ in MDA8 $\mathrm{O}_{3}$ in urban areas (Fig. 4a). $\mathrm{CO}$ is an important $\mathrm{O}_{3}$ precursor and plays a similar role to VOCs in $\mathrm{O}_{3}$ formation, but the changes in its emission have rarely been discussed in previous studies of the causes of variations in $\mathrm{O}_{3}$ concentrations. In fact, our results indicated that the reduction of $\mathrm{CO}$ emissions was the only government-implemented measure that reduced $\mathrm{O}_{3}$ levels in recent years.

In addition to the effects of $\mathrm{O}_{3}$ precursors, the emissions of other pollutants can also affect $\mathrm{O}_{3}$ concentrations by altering photolysis rates and the loss of reactive gases from heterogeneous reactions. The reduction of $\mathrm{SO}_{2}$ emissions increased the $\mathrm{O}_{3}$ levels across China, particularly in northern China and the Sichuan Basin (SCB) (Fig. 3e). Quantitatively, $\mathrm{SO}_{2}$ emission reductions led to an increase of $0.75 \mathrm{ppbv}$ in the MDA8 $\mathrm{O}_{3}$ mixing ratios in urban areas (Fig. 4a), which was the largest cause of $\mathrm{O}_{3}$ increases among all the pollutant emissions changes considered in this work. The $\mathrm{SO}_{2}$ emission was reduced by more than $60 \%$ from 2013 to 2017, which resulted in a significant decrease in ambient $\mathrm{SO}_{4}^{2-}$ concentrations and increased $\mathrm{O}_{3}$ concentrations by increasing the photolysis rates and retarding the loss of reactive gases from heterogeneous reactions. The reduction of $\mathrm{NH}_{3}$ emissions, an important precursor of ammonium, increased the $\mathrm{O}_{3}$ mixing ratio across China in a similar way to the reduction in $\mathrm{SO}_{2}$ emissions (Fig. 3f), but to a small extent, as the $\mathrm{NH}_{3}$ emission was only reduced by $4 \%$. Specifically, the increase in the MDA8 $\mathrm{O}_{3}$ mixing ratios in urban areas due to the reduction of $\mathrm{NH}_{3}$ emissions was only 0.06 ppbv (Fig. 4a), which was an insignificant fraction of the total increases in $\mathrm{O}_{3}$ mixing ratios.

The reduction of primary PM emissions also enhanced $\mathrm{O}_{3}$ formation across China, especially in the NCP and SCB regions (Fig. 3g). The MDA8 $\mathrm{O}_{3}$ mixing ratios increased by $0.72 \mathrm{ppbv}$ due to the PM emission reduction in urban areas (Fig. 4a). The effect of the changes in PM emissions on 

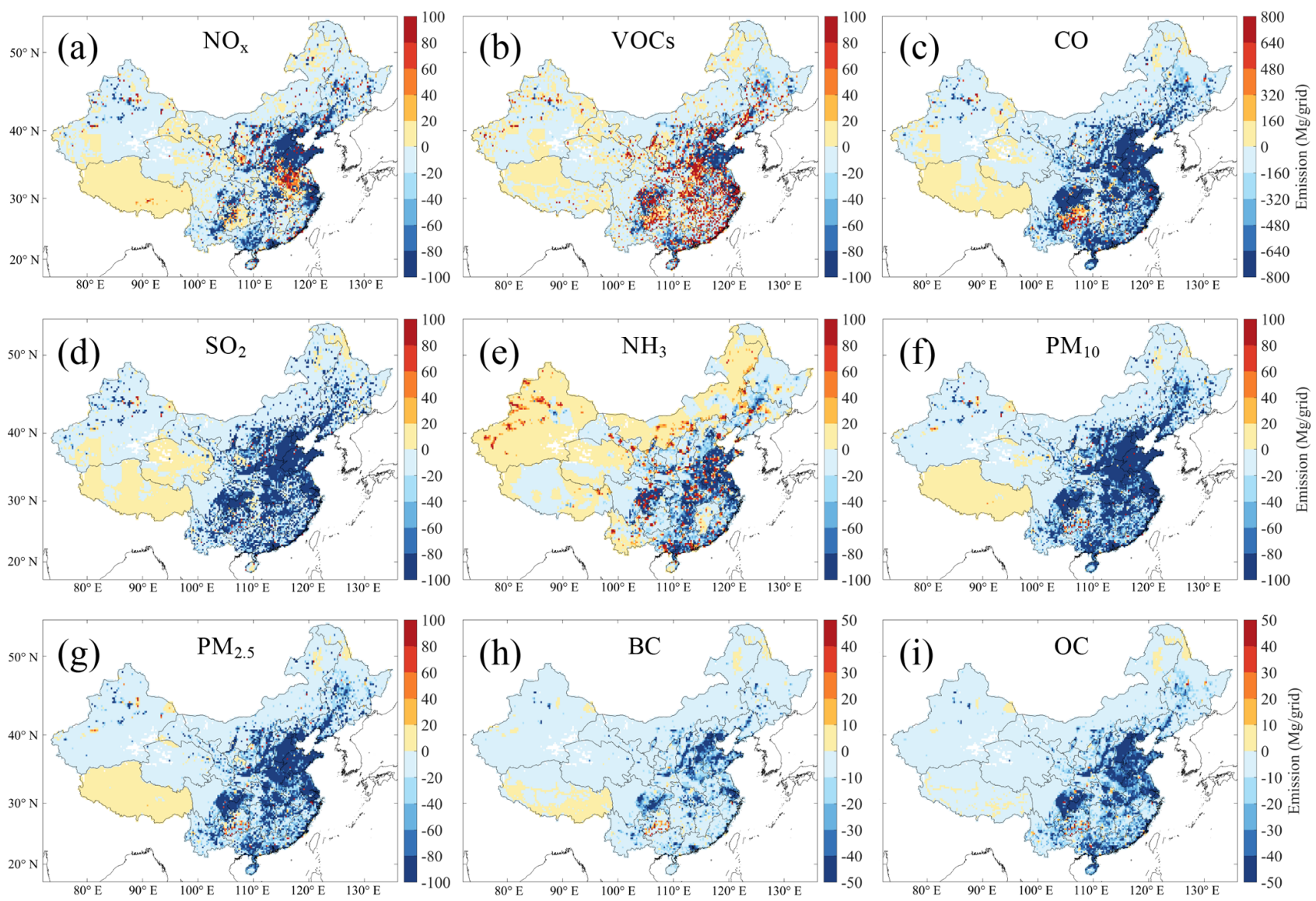

Figure 2. Spatial distributions of changes in anthropogenic pollutant emissions in the summer of 2017 relative to that of 2013 , including (a) $\mathrm{NO}_{x}$, (b) VOCs, (c) CO, (d) $\mathrm{SO}_{2}$, (e) $\mathrm{NH}_{3}$, (f) $\mathrm{PM}_{10}$, (g) $\mathrm{PM}_{2.5}$, (h) BC, and (i) OC. Emission data are obtained from the Multi-resolution Emission Inventory for China (MEIC; http://www.meicmodel.org, last access: 18 January 2020).

$\mathrm{O}_{3}$ levels was comparable with that of the changes in $\mathrm{SO}_{2}$ emissions, which indicated the significant $\mathrm{O}_{3}$-promoting role played by reductions in both primary and secondary aerosols. $\mathrm{BC}$ and $\mathrm{OC}$ are among the components of direct aerosol emissions, and reductions in both were found to increase the $\mathrm{O}_{3}$ levels (Fig. 3h and i). Although the reduction of BC emissions was smaller than the reduction in OC emissions, the increase in MDA8 $\mathrm{O}_{3}$ due to the former was more significant. $\mathrm{BC}$ is an especially strong absorber of visible solar radiation in the atmosphere (Ramanathan and Carmichael, 2008), and therefore greatly retards photolysis rates by reducing the solar radiation reaching the earth's surface.

The dominant cause of $\mathrm{O}_{3}$ increases due to emission changes varied among regions. Figure 4 shows the average changes in $\mathrm{O}_{3}$ mixing ratios due to changes in individual pollutant emissions in four megacities, i.e., Beijing, Shanghai, Guangzhou, and Chengdu (refer to Fig. S1 in Part 1 for their locations), which are the representative cities in the BTH, YRD, Pearl River Delta (PRD), and SCB regions, respectively. In Beijing, $\mathrm{NO}_{x}$ and $\mathrm{PM}$ emission reductions were the two largest causes of rising $\mathrm{O}_{3}$ levels, followed by $\mathrm{SO}_{2}$ emission reductions. Air quality in the BTH region is a ma- jor concern, and strict emission-control measures have been implemented since 2013. As a result, the emissions of $\mathrm{NO}_{x}$, $\mathrm{PM}_{2.5}$, and $\mathrm{SO}_{2}$ in BTH were reduced by $25 \%, 44 \%$, and $65 \%$ from 2013 to 2017 (Fig. S5), respectively, which were generally larger reductions than occurred in other regions (Fig. 2). In Shanghai, the increase in the $\mathrm{O}_{3}$ level was mainly due to the reduction of $\mathrm{NO}_{x}$ emissions and increase in VOC emissions. This result is consistent with the finding of $\mathrm{Yu}$ et al. (2019) using the Kolmogorov-Zurbenko filtering technique, who also suggested that the changes in $\mathrm{O}_{3}$ precursor emissions in the YRD contributed more to $\mathrm{O}_{3}$ increases than did the decrease in $\mathrm{PM}_{2.5}$ concentrations. In the YRD, $\mathrm{NO}_{x}$ emissions decreased by $19 \%$, and that of VOCs increased by $10 \%$ from 2013 to 2017 (Fig. S6). Meanwhile, the $\mathrm{PM}_{2.5}$ concentration in Shanghai was relatively low in summer. As a result, the effects of the $\mathrm{PM}$ and $\mathrm{SO}_{2}$ emission reductions were smaller than those due to the changes in $\mathrm{NO}_{x}$ and $\mathrm{VOC}$ emissions. In Guangzhou, the $\mathrm{NO}_{x}$ emission reduction was the dominant cause of the $\mathrm{O}_{3}$ increase, while the effects of $\mathrm{SO}_{2}$ and $\mathrm{PM}$ emission reductions on $\mathrm{O}_{3}$ levels were insignificant. This result can likewise be ascribed to the low concentration of $\mathrm{PM}_{2.5}$ in summer and relatively large reduc- 

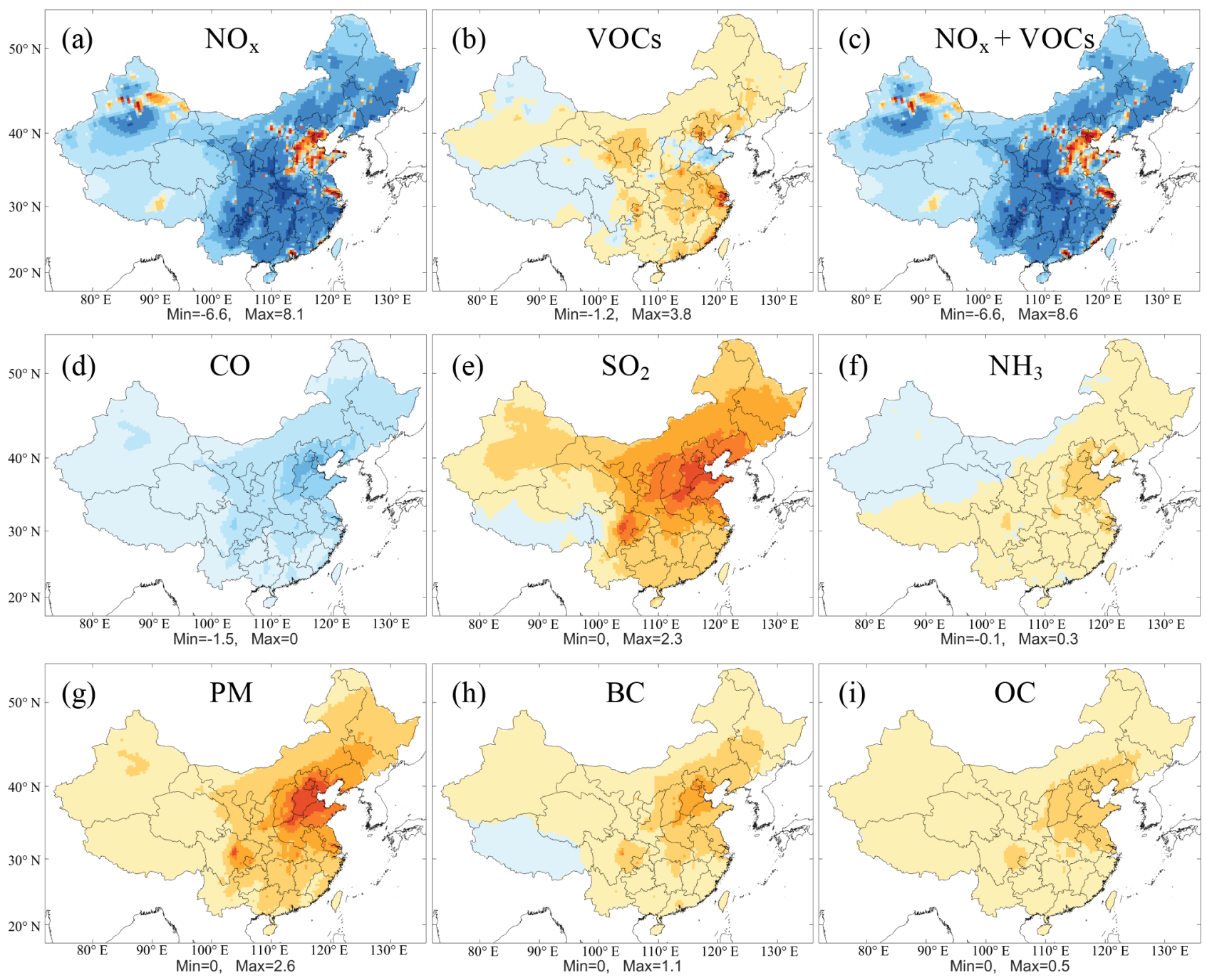

$$
\begin{array}{llllllllllllllll}
-10 & -5 & -3 & -1.5 & -1 & -0.5 & -0.1 & \begin{array}{c}
1 \\
\text { ppbv }
\end{array} & 0.1 & 0.5 & 1 & 1.5 & 3 & 5 & 10
\end{array}
$$

Figure 3. Spatial distribution of the simulated $\mathrm{MDA} 8 \mathrm{O}_{3}$ mixing ratios responding to the changes in individual pollutant emissions in summer from 2013 to 2017, including (a) $\mathrm{NO}_{x}$, (b) VOCs, (c) $\mathrm{NO}_{x}$ and VOCs, (d) $\mathrm{CO}$, (e) $\mathrm{SO}_{2}$, (f) $\mathrm{NH}_{3}$, (g) $\mathrm{PM}$, (h) $\mathrm{BC}$, and (i) $\mathrm{OC}$.

tion of $\mathrm{NO}_{x}$ emissions (Fig. S7) in the PRD. In Chengdu, the $\mathrm{PM}$ and $\mathrm{SO}_{2}$ emission reductions contributed most to the increases in $\mathrm{O}_{3}$ levels. The concentration of $\mathrm{PM}_{2.5}$ in the $\mathrm{SCB}$ was high due to the basin topography and high emissions of both PM and its precursors. The significant reductions of $\mathrm{PM}_{2.5}(35 \%)$ and $\mathrm{SO}_{2}(65 \%)$ emissions in the $\mathrm{SCB}$ (Fig. S8) were thus the two major causes of the $\mathrm{O}_{3}$ increase there. The intercity variations in the dominant causes of increases in $\mathrm{O}_{3}$ concentrations suggest that if the government wishes to alleviate urban $\mathrm{O}_{3}$ pollution, they can adopt additional, localized emission-reduction measures as part of policies (see Sect. 3.5).

\subsection{The effects of aerosol on the $\mathrm{O}_{3}$ variations}

Aerosols in the atmosphere derived from direct emission and secondary formation can reduce photolysis rates and scavenge reactive gases from heterogeneous reactions, thereby inhibiting $\mathrm{O}_{3}$ formation. Figure 5 shows the spatial distribution of changes in the MDA8 $\mathrm{O}_{3}$ mixing ratios due to the changes in the radiative and heterogeneous chemical effects of aerosols from 2013 to 2017 (see Methods section). We isolated the effects of changes in seven heterogeneous reactions on the $\mathrm{O}_{3}$ variations, and the average changes in $\mathrm{O}_{3}$ levels in urban and rural areas are shown in Fig. 6a and b, respectively. As the $\mathrm{PM}_{2.5}$ concentrations decreased substantially due to the reduction of anthropogenic pollutant emis- 

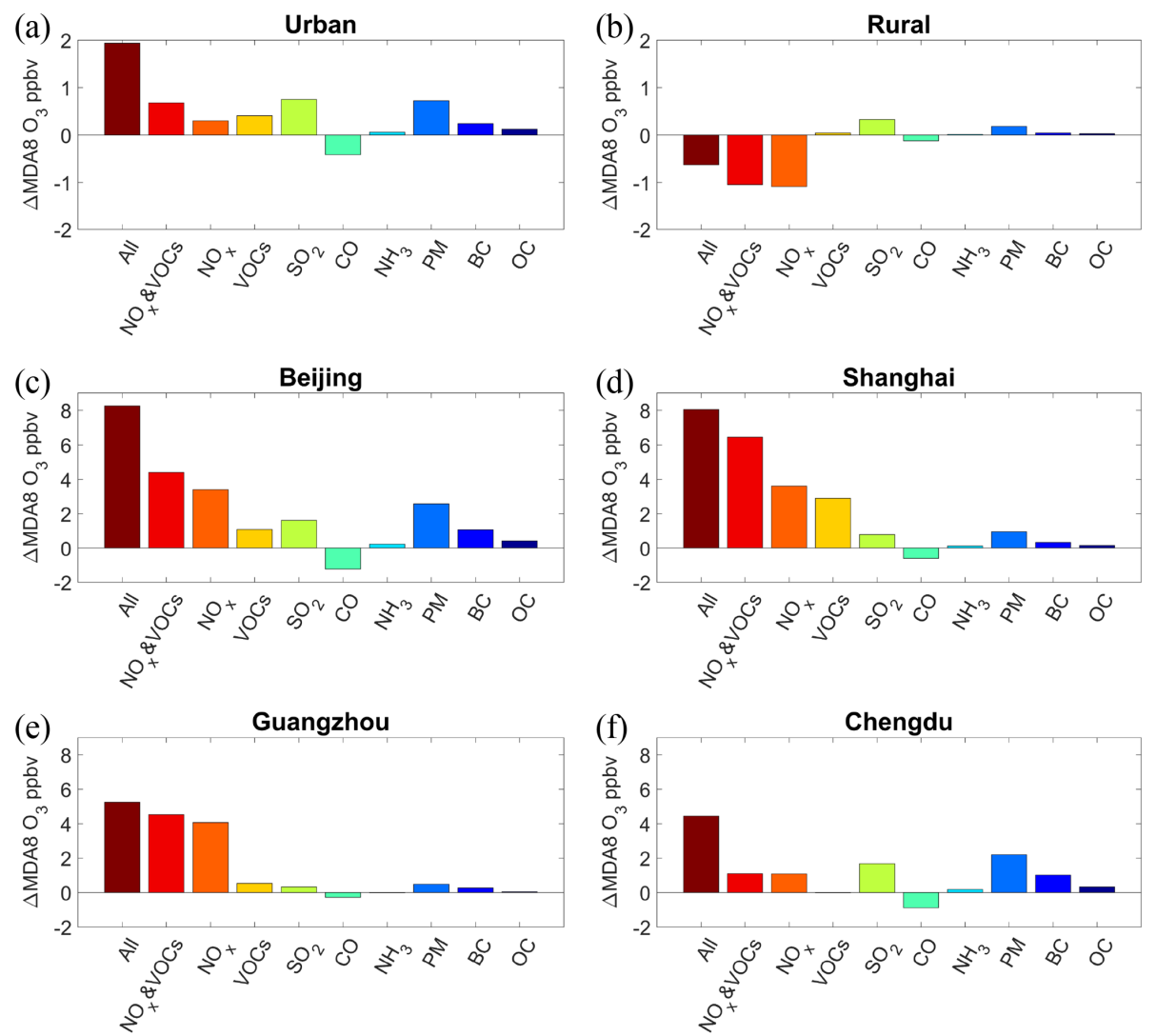

Figure 4. Response of the simulated $\mathrm{MDA} 8 \mathrm{O}_{3}$ mixing ratios to the changes in individual pollutant emissions in summer from 2013 to 2017 in (a) the urban areas, (b) the rural areas, (c) Beijing, (d) Shanghai, (e) Guangzhou, and (f) Chengdu. See Fig. S1 in Part 1 (Liu and Wang, 2020) for the locations of the four megacities.

sions, the effects of aerosols on $\mathrm{O}_{3}$ concentrations also decreased, which led to an increase in $\mathrm{O}_{3}$ levels. The effects of the decrease in $\mathrm{PM}$ concentrations on $\mathrm{O}_{3}$ were insignificant in western China. Significant increases in $\mathrm{O}_{3}$ mixing ratios due to the decrease in various aerosol effects were found in urban and industrial areas of eastern China, particularly the NCP and SCB regions, where pollutant emissions were high and subject to a substantial reduction in the past few years. We found that the heterogeneous chemical effect, rather than the radiative effect, contributed most to the increase in $\mathrm{O}_{3}$ levels driven by changes in PM concentrations. Quantitatively, the changes in photolysis rates and heterogeneous reactions increased the MDA8 $\mathrm{O}_{3}$ mixing ratio by 0.30 and $2.12 \mathrm{ppbv}$ in urban areas, respectively. In rural areas, the MDA8 $\mathrm{O}_{3}$ mixing ratio increased by $0.87 \mathrm{ppbv}$ via the heterogeneous chemical reactions on aerosols, while the effect of changes in photolysis rates was negligible. As for various heterogeneous reactions, the changes in individual reactions all increased MDA8 $\mathrm{O}_{3}$ from 2013 to 2017. The decrease in the aerosol-sink effect of $\mathrm{HO}_{2}$ contributed most to the $\mathrm{O}_{3}$ increase due to changes in PM concentrations, followed by $\mathrm{O}_{3}, \mathrm{~N}_{2} \mathrm{O}_{5}$, and $\mathrm{H}_{2} \mathrm{O}_{2}$. The effects of changes in the hetero- geneous reactions of $\mathrm{NO}_{2}, \mathrm{NO}_{3}$, and $\mathrm{OH}$ on the increase in $\mathrm{O}_{3}$ levels were small.

The effect of the decrease in aerosol concentrations on $\mathrm{O}_{3}$ levels varied by city. Significant effects were found in Beijing and Chengdu, where the $\mathrm{PM}_{2.5}$ concentration was high and was subject to a large reduction by the implementation of emission-control measures. In contrast, the $\mathrm{PM}_{2.5}$ concentration was lower in Shanghai and Guangzhou, and their $\mathrm{O}_{3}$ levels were less affected by the decrease in aerosol concentrations.

$\mathrm{Li}$ et al. (2019) also investigated the effects of changes in photolysis rates and heterogeneous reactions on $\mathrm{O}_{3}$ levels, using the GEOS-Chem model incorporating heterogeneous reactions of nitrogen oxides and $\mathrm{HO}_{2}$. They quantified the effect of changes in photolysis rates by scaling the aerosolextinction rate using the satellite-based aerosol optical depth changes and the effect of changes in heterogeneous reactions by scaling the aerosol surface area using the measurementbased $\mathrm{PM}_{2.5}$ changes from 2013 to 2017. They concluded that the increase in $\mathrm{O}_{3}$ mixing ratios due to changes in $\mathrm{PM}$ concentrations could be largely ascribed to the decrease in the effect of $\mathrm{HO}_{2}$ heterogeneous reaction. Using a regional model and adopting different experimental settings, our work 

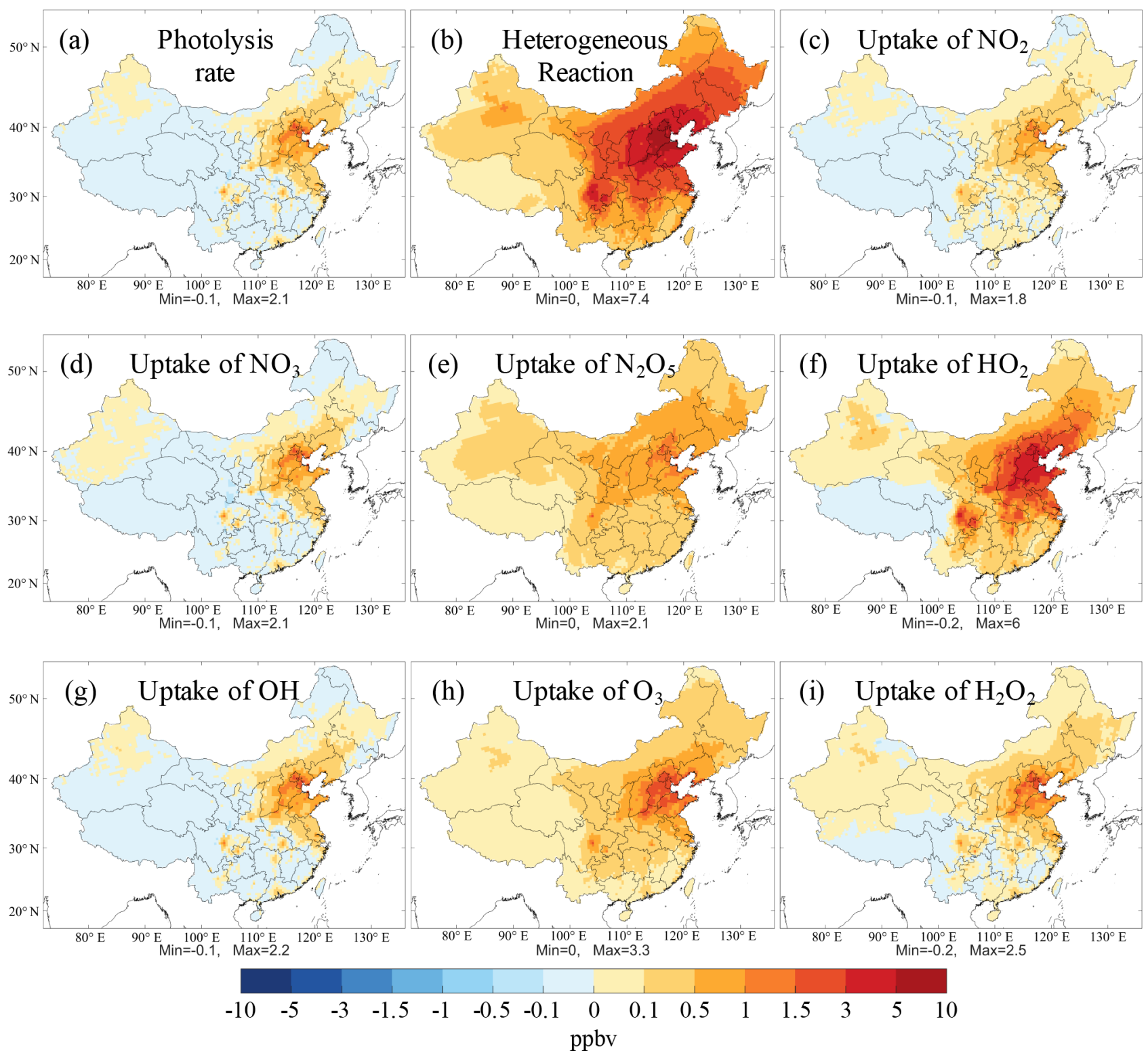

Figure 5. Spatial distribution of the simulated $\mathrm{MDA} 8 \mathrm{O}_{3}$ mixing ratios responding to the changes in the effects of aerosol in summer from 2013 to 2017 (see Methods section). The aerosol affects $\mathrm{O}_{3}$ via altering (a) photolysis rates, (b) all heterogeneous reactions, and individual heterogeneous reactions, namely the uptake of (c) $\mathrm{NO}_{2}$, (d) $\mathrm{NO}_{3}$, (e) $\mathrm{N}_{2} \mathrm{O}_{5}$, (f) $\mathrm{HO}_{2}$, (g) $\mathrm{OH}$, (h) $\mathrm{O}_{3}$, and (i) $\mathrm{H}_{2} \mathrm{O}_{2}$.

uncovered a similar and substantial effect of $\mathrm{HO}_{2}$ uptake on increases in $\mathrm{O}_{3}$ levels due to changes in PM concentrations. In addition, with more heterogeneous reactions implemented in the CMAQ model, we found that the uptake of $\mathrm{O}_{3}$ on aerosol surfaces was also important, following $\mathrm{HO}_{2}$.

\subsection{The anthropogenic VOCs emission controls to reduce $\mathrm{O}_{3}$}

The results in the preceding sections show that although the $\mathrm{CO}$ emission reductions contributed to a decrease in $\mathrm{O}_{3}$ levels, the reductions of $\mathrm{SO}_{2}, \mathrm{NO}_{x}$, and $\mathrm{PM}$ emissions had a counterproductive effect on $\mathrm{O}_{3}$ reductions, resulting in a substantial increase in urban $\mathrm{O}_{3}$ concentrations due to the nonlinear $\mathrm{NO}_{x}$ and $\mathrm{VOC}$ chemistry and the weakening of aerosol effects. To alleviate these negative effects of PM-targeted control policies and thereby reduce ambient $\mathrm{O}_{3}$ concentrations, we found that anthropogenic VOC emissions must also be reduced alongside reductions in emissions of other pollutants.

Figure 7 presents the changes in the MDA8 $\mathrm{O}_{3}$ mixing ratios from its 2013 value, where the 2013 VOC emissions were decreased from $0 \%$ to $50 \%$, while the 2017 emissions of other pollutants were retained (see Methods section). The 

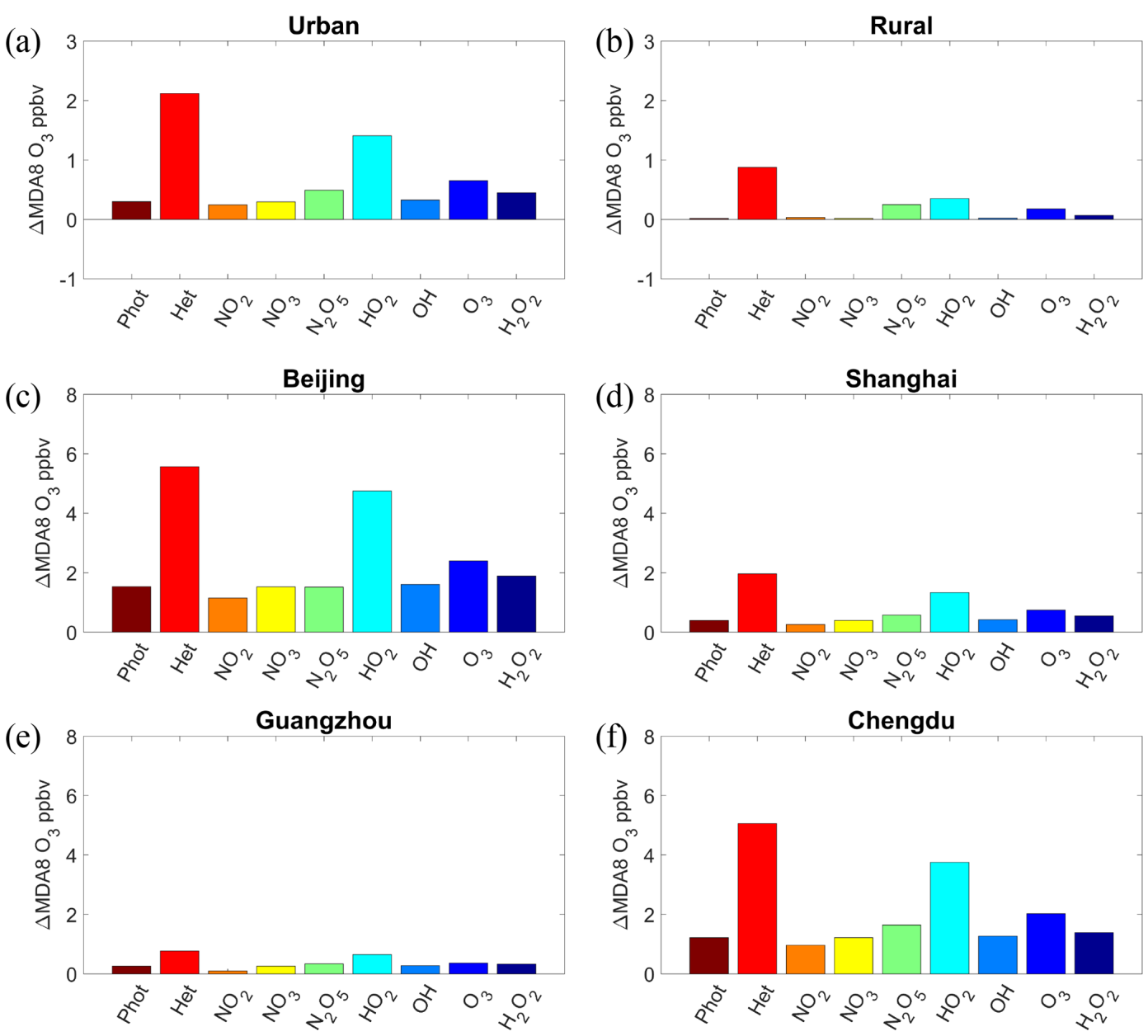

Figure 6. Response of the simulated MDA8 $\mathrm{O}_{3}$ mixing ratios to the changes in the effects of aerosols in summer from 2013 to 2017 in (a) the urban area, (b) the rural area, (c) Beijing, (d) Shanghai, (e) Guangzhou, and (f) Chengdu. The aerosol affects $\mathrm{O}_{3}$ via altering the photolysis rates (Phot), all heterogeneous reactions (Het), and individual heterogeneous reactions, namely the uptake of $\mathrm{NO}_{2}, \mathrm{NO}_{3}, \mathrm{~N}_{2} \mathrm{O}_{5}, \mathrm{HO}_{2}, \mathrm{OH}_{\text {, }}$ $\mathrm{O}_{3}$, and $\mathrm{H}_{2} \mathrm{O}_{2}$.

MDA8 $\mathrm{O}_{3}$ mixing ratios in the four studied megacities decrease linearly with the reduction of VOC emissions, reflecting that $\mathrm{O}_{3}$ formation in these cities is VOCs limited. Compared with the $\mathrm{O}_{3}$ level in 2013, the VOC emissions would have needed to be reduced by approximately $20 \%$ to prevent increases in MDA8 $\mathrm{O}_{3}$ from 2013 to 2017. This suggests that the adverse effects of the reductions of $\mathrm{NO}_{x}, \mathrm{SO}_{2}$, and $\mathrm{PM}$ emissions on urban $\mathrm{O}_{3}$ could have been avoided with a $\sim 20 \%$ reduction of VOC emissions from 2013 to 2017. The exact reductions of VOC emissions required vary among the four megacities: Beijing (24\%), Shanghai (23\%), Guangzhou (20\%), and Chengdu (16\%). In Beijing (BTH region), the drastic reductions of $\mathrm{NO}_{x}, \mathrm{SO}_{2}$, and $\mathrm{PM}$ emissions would have necessitated a more substantial reduction of VOC emissions to counteract the $\mathrm{O}_{3}$ increase. In Shanghai (YRD region) and Guangzhou (PRD region), the increase in $\mathrm{O}_{3}$ concentrations due to the reductions in $\mathrm{NO}_{x}$ emissions also calls for a significant reduction in VOC emissions. In
Chengdu (SCB region), a smaller VOCs emission reduction is needed because of the relatively small increase in $\mathrm{O}_{3}$ concentrations due to changes in other emissions. We also found that the required percentage reductions of VOC emissions in each city were comparable with the actual percentage reductions in $\mathrm{NO}_{x}$ emissions $(25 \%, 19 \%, 18 \%$, and $14 \%$ for Beijing, Shanghai, Guangzhou, and Chengdu, respectively), suggesting that similar percentage reductions of VOCs and $\mathrm{NO}_{x}$ would have prevented the increase in $\mathrm{O}_{3}$ levels from 2013 to 2017.

Our results have important implications for air-pollution control policy in the coming years. In 2018, the Chinese government issued a Three-Year Action Plan (20182020) mandating further reductions of national $\mathrm{SO}_{2}$ and $\mathrm{NO}_{x}$ emissions by at least $15 \%$ by the year 2020 compared with those in the year 2015 and an $18 \%$ reduction in ambient $\mathrm{PM}_{2.5}$ concentrations in cities currently not compliant with China's $\mathrm{PM}_{2.5}$ standards (http://www.gov.cn/ 


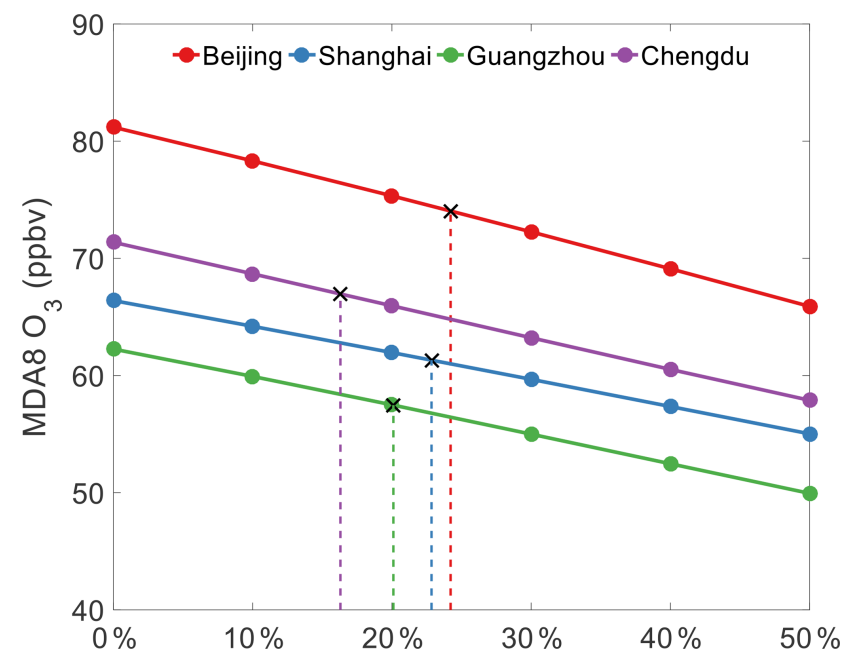

Figure 7. Response of simulated MDA $8 \mathrm{O}_{3}$ mixing ratios with 2017 emissions (except for VOCs) to the reductions of anthropogenic VOCs from the 2013 level in summer in Beijing, Shanghai, Guangzhou, and Chengdu. The black crosses depict the MDA8 values in 2013 and the required reduction of VOC emissions in 2017 to maintain the $2013 \mathrm{O}_{3}$ level in each city.

zhengce/content/2018-07/03/content_5303158.htm, last access: 18 January 2020). This implies that if VOC emissions are not reduced in the near future, the $\mathrm{O}_{3}$ pollution in major cities will continue to worsen. Therefore, we suggest that VOC emission controls be implemented together with the PM-targeted measures in order to alleviate the urban $\mathrm{O}_{3}$ pollution.

\section{Conclusions}

This study has quantified the effects of changes in pollutant emissions from anthropogenic activities on the summer surface $\mathrm{O}_{3}$ concentrations over China from 2013 to 2017. The control measures, while successful in reducing the concentrations of primary pollutants and particulate matter, were found to increase urban $\mathrm{O}_{3}$ but reduce rural $\mathrm{O}_{3}$; overall, the $\mathrm{NO}_{x}$ emission reduction has helped to contain total ozone production in China. The reduction in $\mathrm{NO}_{x}$ emission and slight increase in VOC emissions led to ozone increase in urban areas due to the nonlinear chemistry of $\mathrm{O}_{3}$, and the large reductions in $\mathrm{PM}$ and $\mathrm{SO}_{2}$ emissions contributed to urban ozone increase resulting from the complex effects of aerosols on radiation and chemical reactions. Among the primary PM components, the emission decrease in $\mathrm{BC}$ increased $\mathrm{O}_{3}$ more than that for $\mathrm{OC}$ despite its smaller reduction compared to $\mathrm{OC}$, resulting from $\mathrm{BC}$ being a strong absorber of solar radiation. The dominant causes of the urban ozone increase due to emission change varied among different cities, and they were $\mathrm{NO}_{x}$ and PM in Beijing, $\mathrm{NO}_{x}$ and VOC in Shanghai, $\mathrm{NO}_{x}$ in Guangzhou, and $\mathrm{PM}$ and $\mathrm{SO}_{2}$ in Chengdu. For the aerosol effects, the decrease in heterogeneous uptake of reactive gases was more important than the increase in photolysis rates. Only the $\mathrm{CO}$ emission cut helped to decrease urban ozone. Our results show that comparable percentage reductions in anthropogenic VOCs to that achieved for $\mathrm{NO}_{x}$ could have prevented the increases in urban $\mathrm{O}_{3}$ concentrations. We thus recommend that VOCs controls be implemented in current and future emission-reduction measures to improve the overall air quality. In view of the importance and complexity of the uptake of reactive gases on aerosol surfaces, more research should be conducted in this area.

Code and data availability. The code or data used in this study are available upon request from Yiming Liu (yming.liu@ polyu.edu.hk) and Tao Wang (cetwang@polyu.edu.hk).

Supplement. The supplement related to this article is available online at: https://doi.org/10.5194/acp-20-6323-2020-supplement.

Author contributions. TW initiated the research. YL and TW designed the research framework. YL modified the model and performed model simulations. TW and YL analyzed the results and wrote the paper.

Competing interests. The authors declare that they have no conflict of interest.

Acknowledgements. We would like to thank Qiang Zhang from Tsinghua University for providing the emission inventory, and Xiao Fu from The Hong Kong Polytechnic University for sharing the model codes of HONO sources.

Financial support. This research has been supported by the Hong Kong Research Grants Council (grant no. T24-504/17-N) and the National Natural Science Foundation of China (grant no. 91844301).

Review statement. This paper was edited by Qiang Zhang and reviewed by two anonymous referees.

\section{References}

Abbatt, J. P. D. and Waschewsky, G. C. G.: Heterogeneous Interactions of $\mathrm{HOBr}, \mathrm{HNO}_{3}, \mathrm{O}_{3}$, and $\mathrm{NO}_{2}$ with Deliquescent $\mathrm{NaCl}$ Aerosols at Room Temperature, J. Phys. Chem. A, 102, 37193725, https://doi.org/10.1021/jp980932d, 1998.

Atkinson, R.: Atmospheric chemistry of VOCs and $\mathrm{NO}_{x}$, Atmos. Environ., 34, 2063-2101, https://doi.org/10.1016/S13522310(99)00460-4, 2000. 
Bauer, S. E., Balkanski, Y., Schulz, M., Hauglustaine, D. A., and Dentener, F.: Global modeling of heterogeneous chemistry on mineral aerosol surfaces: Influence on tropospheric ozone chemistry and comparison to observations, J. Geophys. Res.-Atmos., 109, D02304, https://doi.org/10.1029/2003jd003868, 2004.

Bertram, T. H. and Thornton, J. A.: Toward a general parameterization of $\mathrm{N}_{2} \mathrm{O}_{5}$ reactivity on aqueous particles: the competing effects of particle liquid water, nitrate and chloride, Atmos. Chem. Phys., 9, 8351-8363, https://doi.org/10.5194/acp-9-8351-2009, 2009.

Binkowski, F. S., Arunachalam, S., Adelman, Z., and Pinto, J. P.: Examining photolysis rates with a prototype online photolysis module in CMAQ, 46, 1252-1256, https://doi.org/10.1175/jam2531.1, 2007.

Byun, D. and Schere, K. L.: Review of the governing equations, computational algorithms, and other components of the models3 Community Multiscale Air Quality (CMAQ) modeling system, Appl. Mech. Rev., 59, 51-77, https://doi.org/10.1115/1.2128636, 2006.

DeMore, W. B., Sander, S. P., Golden, D. M., Hampson, R. F., Kurylo, M. J., Howard, C. J., Ravishankara, A. R., Kolb, C. E., and Molina, M. J.: Chemical kinetics and photochemical data for use in stratospheric modeling, National Aeronautics and Space Administration and Jet Propulsion Laboratory, California Institute of Technology, California, 1997.

de Reus, M., Fischer, H., Sander, R., Gros, V., Kormann, R., Salisbury, G., Van Dingenen, R., Williams, J., Zöllner, M., and Lelieveld, J.: Observations and model calculations of trace gas scavenging in a dense Saharan dust plume during MINATROC, Atmos. Chem. Phys., 5, 1787-1803, https://doi.org/10.5194/acp5-1787-2005, 2005.

Exner, M., Herrmann, H., and Zellner, R.: Laser-based studies of reactions of the nitrate radical in aqueous solution, Berichte der Bunsengesellschaft für physikalische Chemie, 96, 470-477, https://doi.org/10.1002/bbpc.19920960347, 1992.

Fu, X., Wang, T., Zhang, L., Li, Q., Wang, Z., Xia, M., Yun, H., Wang, W., Yu, C., Yue, D., Zhou, Y., Zheng, J., and Han, R.: The significant contribution of HONO to secondary pollutants during a severe winter pollution event in southern China, Atmos. Chem. Phys., 19, 1-14, https://doi.org/10.5194/acp-19-1-2019, 2019.

Fuchs, H., Bohn, B., Hofzumahaus, A., Holland, F., Lu, K. D., Nehr, S., Rohrer, F., and Wahner, A.: Detection of $\mathrm{HO}_{2}$ by laser-induced fluorescence: calibration and interferences from $\mathrm{RO}_{2}$ radicals, Atmos. Meas. Tech., 4, 1209-1225, https://doi.org/10.5194/amt-4-1209-2011, 2011.

George, I. J., Matthews, P. S. J., Whalley, L. K., Brooks, B., Goddard, A., Baeza-Romero, M. T., and Heard, D. E.: Measurements of uptake coefficients for heterogeneous loss of $\mathrm{HO}_{2}$ onto submicron inorganic salt aerosols, Phys. Chem. Chem. Phys., 15, 12829-12845, https://doi.org/10.1039/c3cp51831k, 2013.

Guo, S., Hu, M., Zamora, M. L., Peng, J. F., Shang, D. J., Zheng, J., Du, Z. F., Wu, Z., Shao, M., Zeng, L. M., Molina, M. J., and Zhang, R. Y.: Elucidating severe urban haze formation in China, P. Natl. Acad. Sci. USA, 111, 17373-17378, https://doi.org/10.1073/pnas.1419604111, 2014.

Hanisch, F. and Crowley, J. N.: Ozone decomposition on Saharan dust: an experimental investigation, Atmos. Chem. Phys., 3, 119130, https://doi.org/10.5194/acp-3-119-2003, 2003.
Huang, R. J., Zhang, Y. L., Bozzetti, C., Ho, K. F., Cao, J. J., Han, Y. M., Daellenbach, K. R., Slowik, J. G., Platt, S. M., Canonaco, F., Zotter, P., Wolf, R., Pieber, S. M., Bruns, E. A., Crippa, M., Ciarelli, G., Piazzalunga, A., Schwikowski, M., Abbaszade, G., Schnelle-Kreis, J., Zimmermann, R., An, Z. S., Szidat, S., Baltensperger, U., El Haddad, I., and Prevot, A. S. H.: High secondary aerosol contribution to particulate pollution during haze events in China, Nature, 514, 218-222, https://doi.org/10.1038/nature13774, 2014.

Huijnen, V., Williams, J. E., and Flemming, J.: Modeling global impacts of heterogeneous loss of $\mathrm{HO}_{2}$ on cloud droplets, ice particles and aerosols, Atmos. Chem. Phys. Discuss., 14, 8575-8632, https://doi.org/10.5194/acpd-14-8575-2014, 2014.

Jacob, D. J.: Heterogeneous chemistry and tropospheric ozone, Atmos. Environ., 34, 2131-2159, 2000.

Kurtenbach, R., Becker, K. H., Gomes, J. A. G., Kleffmann, J., Lorzer, J. C., Spittler, M., Wiesen, P., Ackermann, R., Geyer, A., and Platt, U.: Investigations of emissions and heterogeneous formation of HONO in a road traffic tunnel, Atmos. Environ., 35, 3385-3394, https://doi.org/10.1016/s1352-2310(01)00138$8,2001$.

Li, J., Wang, Z., Wang, X., Yamaji, K., Takigawa, M., Kanaya, Y., Pochanart, P., Liu, Y., Irie, H., Hu, B., Tanimoto, H., and Akimoto, H.: Impacts of aerosols on summertime tropospheric photolysis frequencies and photochemistry over Central Eastern China, Atmos. Environ., 45, 1817-1829, https://doi.org/10.1016/j.atmosenv.2011.01.016, 2011.

Li, J., Chen, X. S., Wang, Z. F., Du, H. Y., Yang, W. Y., Sun, Y. L., Hu, B., Li, J. J., Wang, W., Wang, T., Fu, P. Q., and Huang, H. L.: Radiative and heterogeneous chemical effects of aerosols on ozone and inorganic aerosols over East Asia, Sci. Total Environ., 622, 1327-1342, https://doi.org/10.1016/j.scitotenv.2017.12.041, 2018.

Li, K., Jacob, D. J., Liao, H., Shen, L., Zhang, Q., and Bates, K. H.: Anthropogenic drivers of 2013-2017 trends in summer surface ozone in China, P. Natl. Acad. Sci. USA, 116, 422-427, 2019.

Li, S. W., Liu, W. Q., Xie, P. H., Qin, M., and Yang, Y. J.: Observation of nitrate radical in the nocturnal boundary layer during a summer field campaign in Pearl River Delta, China, Terr. Atmos. Ocean. Sci., 23, 39-48, https://doi.org/10.3319/Tao.2011.07.26.01(a), 2012.

Li, X., Brauers, T., Häseler, R., Bohn, B., Fuchs, H., Hofzumahaus, A., Holland, F., Lou, S., Lu, K. D., Rohrer, F., Hu, M., Zeng, L. M., Zhang, Y. H., Garland, R. M., Su, H., Nowak, A., Wiedensohler, A., Takegawa, N., Shao, M., and Wahner, A.: Exploring the atmospheric chemistry of nitrous acid (HONO) at a rural site in Southern China, Atmos. Chem. Phys., 12, 1497-1513, https://doi.org/10.5194/acp-12-1497-2012, 2012.

Li, Z. Y., Xue, L. K., Yang, X., Zha, Q. Z., Tham, Y. J., Yan, C., Louie, P. K. K., Luk, C. W. Y., Wang, T., and Wang, W. X.: Oxidizing capacity of the rural atmosphere in Hong Kong, Southern China, Sci. Total Environ., 612, 1114-1122, https://doi.org/10.1016/j.scitotenv.2017.08.310, 2018.

Liang, H., Chen, Z. M., Huang, D., Zhao, Y., and Li, Z. Y.: Impacts of aerosols on the chemistry of atmospheric trace gases: a case study of peroxides and $\mathrm{HO}_{2}$ radicals, Atmos. Chem. Phys., 13, 11259-11276, https://doi.org/10.5194/acp-13-112592013, 2013. 
Liao, H. and Seinfeld, J. H.: Global impacts of gas-phase chemistryaerosol interactions on direct radiative forcing by anthropogenic aerosols and ozone, J. Geophys. Res.-Atmos., 110, D18208, https://doi.org/10.1029/2005jd005907, 2005.

Liao, H., Seinfeld, J. H., Adams, P. J., and Mickley, L. J.: Global radiative forcing of coupled tropospheric ozone and aerosols in a unified general circulation model, J. Geophys. Res.-Atmos., 109, D16207, 2004.

Liu, Y. and Wang, T.: Worsening urban ozone pollution in China from 2013 to 2017 - Part 1: The complex and varying roles of meteorology, Atmos. Chem. Phys., 20, 6305-6321, https://doi.org/10.5194/acp-20-6305-2020, 2020.

Longfellow, C. A., Ravishankara, A. R., and Hanson, D. R.: Reactive and nonreactive uptake on hydrocarbon soot: $\mathrm{HNO}_{3}, \mathrm{O}_{3}$, and $\mathrm{N}_{2} \mathrm{O}_{5}, 105,24345-24350$, https://doi.org/10.1029/2000jd900297, 2000.

Lou, S. J., Liao, H., and Zhu, B.: Impacts of aerosols on surfacelayer ozone concentrations in China through heterogeneous reactions and changes in photolysis rates, Atmos. Environ., 85, 123138, https://doi.org/10.1016/j.atmosenv.2013.12.004, 2014.

Lu, K. D., Rohrer, F., Holland, F., Fuchs, H., Bohn, B., Brauers, T., Chang, C. C., Häseler, R., Hu, M., Kita, K., Kondo, Y., Li, X., Lou, S. R., Nehr, S., Shao, M., Zeng, L. M., Wahner, A., Zhang, Y. H., and Hofzumahaus, A.: Observation and modelling of $\mathrm{OH}$ and $\mathrm{HO}_{2}$ concentrations in the Pearl River Delta 2006: a missing $\mathrm{OH}$ source in a VOC rich atmosphere, Atmos. Chem. Phys., 12, 1541-1569, https://doi.org/10.5194/acp-12-1541-2012, 2012.

Lu, K. D., Hofzumahaus, A., Holland, F., Bohn, B., Brauers, T., Fuchs, H., Hu, M., Häseler, R., Kita, K., Kondo, Y., Li, X., Lou, S. R., Oebel, A., Shao, M., Zeng, L. M., Wahner, A., Zhu, T., Zhang, Y. H., and Rohrer, F.: Missing $\mathrm{OH}$ source in a suburban environment near Beijing: observed and modelled $\mathrm{OH}$ and $\mathrm{HO}_{2}$ concentrations in summer 2006, Atmos. Chem. Phys., 13, 10571080, https://doi.org/10.5194/acp-13-1057-2013, 2013.

Lu, X., Hong, J. Y., Zhang, L., Cooper, O. R., Schultz, M. G., Xu, X. B., Wang, T., Gao, M., Zhao, Y. H., and Zhang, Y. H.: Severe surface ozone pollution in China: A global perspective, Environ. Sci. Tech. Lett., 5, 487-494, https://doi.org/10.1021/acs.estlett.8b00366, 2018.

Mao, J. Q., Paulot, F., Jacob, D. J., Cohen, R. C., Crounse, J. D., Wennberg, P. O., Keller, C. A., Hudman, R. C., Barkley, M. P., and Horowitz, L. W.: Ozone and organic nitrates over the eastern United States: Sensitivity to isoprene chemistry, J. Geophys. Res.-Atmos., 118, 11256-11268, 2013.

Michel, A. E., Usher, C. R., and Grassian, V. H.: Heterogeneous and catalytic uptake of ozone on mineral oxides and dusts: A Knudsen cell investigation, Geophys. Res. Lett., 29, 1665, https://doi.org/10.1029/2002gl014896, 2002.

Michel, A. E., Usher, C. R., and Grassian, V. H.: Reactive uptake of ozone on mineral oxides and mineral dusts, Atmos. Environ., 37, 3201-3211, https://doi.org/10.1016/S1352-2310(03)003194, 2003.

Moise, T., Talukdar, R. K., Frost, G. J., Fox, R. W., and Rudich, Y.: Reactive uptake of $\mathrm{NO}_{3}$ by liquid and frozen organics, 107, 4041, https://doi.org/10.1029/2001jd000334, 2002.

Ndour, M., D’Anna, B., George, C., Ka, O., Balkanski, Y., Kleffmann, J., Stemmler, K., and Ammann, M.: Photoenhanced uptake of $\mathrm{NO}_{2}$ on mineral dust: Laboratory experi- ments and model simulations, Geophys. Res. Lett., 35, L05812, https://doi.org/10.1029/2007gl032006, 2008.

NRC: Rethinking the ozone problem in urban and regional air pollution, National Academy Press, Washington, D.C., 1991.

Pozzoli, L., Bey, I., Rast, S., Schultz, M. G., Stier, P., and Feichter, J.: Trace gas and aerosol interactions in the fully coupled model of aerosol-chemistry-climate ECHAM5-HAMMOZ: 1. Model description and insights from the spring 2001 TRACE-P experiment, J. Geophys. Res.-Atmos., 113, D07308, https://doi.org/10.1029/2007jd009007, 2008.

Qin, M., Xie, P., Su, H., Gu, J., Peng, F., Li, S., Zeng, L., Liu, J., Liu, W., and Zhang, Y.: An observational study of the $\mathrm{HONO}-\mathrm{NO}_{2}$ coupling at an urban site in Guangzhou City, South China, Atmos. Environ., 43, 5731-5742, https://doi.org/10.1016/j.atmosenv.2009.08.017, 2009.

Qin, M. R., Chen, Z. M., Shen, H. Q., Li, H., Wu, H. H., and Wang, Y.: Impacts of heterogeneous reactions to atmospheric peroxides: Observations and budget analysis study, Atmos. Environ., 183, 144-153, https://doi.org/10.1016/j.atmosenv.2018.04.005, 2018.

Ramanathan, V. and Carmichael, G.: Global and regional climate changes due to black carbon, Nat. Geosci., 1, 221-227, https://doi.org/10.1038/ngeo156, 2008.

Rudich, Y., Talukdar, R. K., Ravishankara, A. R., and Fox, R. W.: Reactive uptake of $\mathrm{NO}_{3}$ on pure water and ionic solutions, J. Geophys. Res.-Atmos., 101, 21023-21031, https://doi.org/10.1029/96jd01844, 1996.

Sarwar, G., Simon, H., Bhave, P., and Yarwood, G.: Examining the impact of heterogeneous nitryl chloride production on air quality across the United States, Atmos. Chem. Phys., 12, 6455-6473, https://doi.org/10.5194/acp-12-6455-2012, 2012.

Stadtler, S., Simpson, D., Schröder, S., Taraborrelli, D., Bott, A., and Schultz, M.: Ozone impacts of gas-aerosol uptake in global chemistry transport models, Atmos. Chem. Phys., 18, 31473171, https://doi.org/10.5194/acp-18-3147-2018, 2018.

Stemmler, K., Ndour, M., Elshorbany, Y., Kleffmann, J., D’Anna, B., George, C., Bohn, B., and Ammann, M.: Light induced conversion of nitrogen dioxide into nitrous acid on submicron humic acid aerosol, Atmos. Chem. Phys., 7, 4237-4248, https://doi.org/10.5194/acp-7-4237-2007, 2007.

Stutz, J., Alicke, B., Ackermann, R., Geyer, A., Wang, S., White, A. B., Williams, E. J., Spicer, C. W., and Fast, J. D.: Relative humidity dependence of HONO chemistry in urban areas, J. Geophys. Res.-Atmos., 109, D03307, https://doi.org/10.1029/2003jd004135, 2004.

Tan, Z., Fuchs, H., Lu, K., Hofzumahaus, A., Bohn, B., Broch, S., Dong, H., Gomm, S., Häseler, R., He, L., Holland, F., Li, X., Liu, Y., Lu, S., Rohrer, F., Shao, M., Wang, B., Wang, M., Wu, Y., Zeng, L., Zhang, Y., Wahner, A., and Zhang, Y.: Radical chemistry at a rural site (Wangdu) in the North China Plain: observation and model calculations of $\mathrm{OH}, \mathrm{HO}_{2}$ and $\mathrm{RO}_{2}$ radicals, Atmos. Chem. Phys., 17, 663-690, https://doi.org/10.5194/acp17-663-2017, 2017.

Tham, Y. J., Yan, C., Xue, L. K., Zha, Q. Z., Wang, X. F., and Wang, T.: Presence of high nitryl chloride in Asian coastal environment and its impact on atmospheric photochemistry, Chinese Sci. Bull., 59, 356-359, https://doi.org/10.1007/s11434-013-0063-y, 2014.

Tham, Y. J., Wang, Z., Li, Q., Yun, H., Wang, W., Wang, X., Xue, L., Lu, K., Ma, N., Bohn, B., Li, X., Kecorius, S., Größ, J., Shao, M., 
Wiedensohler, A., Zhang, Y., and Wang, T.: Significant concentrations of nitryl chloride sustained in the morning: investigations of the causes and impacts on ozone production in a polluted region of northern China, Atmos. Chem. Phys., 16, 14959-14977, https://doi.org/10.5194/acp-16-14959-2016, 2016.

Wang, J. Q., Zhang, X. S., Guo, J., Wang, Z. W., and Zhang, M. G.: Observation of nitrous acid (HONO) in Beijing, China: Seasonal variation, nocturnal formation and daytime budget, Sci. Total Environ., 587, 350-359, https://doi.org/10.1016/j.scitotenv.2017.02.159, 2017.

Wang, N., Lyu, X. P., Deng, X. J., Huang, X., Jiang, F., and Ding, A. J.: Aggravating $\mathrm{O}_{3}$ pollution due to $\mathrm{NO}_{x}$ emission control in eastern China, Sci. Total Environ., 677, 732-744, https://doi.org/10.1016/j.scitotenv.2019.04.388, 2019.

Wang, P. F., Guo, H., Hu, J. L., Kota, S. H., Ying, Q., and Zhang, $\mathrm{H}$.: Responses of $\mathrm{PM}_{2.5}$ and $\mathrm{O}_{3}$ concentrations to changes of meteorology and emissions in China, Sci. Total Environ., 662, 297-306, https://doi.org/10.1016/j.scitotenv.2019.01.227, 2019.

Wang, S. S., Shi, C. Z., Zhou, B., Zhao, H., Wang, Z. R., Yang, S. N., and Chen, L. M.: Observation of $\mathrm{NO}_{3}$ radicals over Shanghai, China, Atmos. Environ., 70, 401-409, https://doi.org/10.1016/j.atmosenv.2013.01.022, 2013.

Wang, T., Xue, L. K., Brimblecombe, P., Lam, Y. F., Li, L., and Zhang, L.: Ozone pollution in China: A review of concentrations, meteorological influences, chemical precursors, and effects, Sci. Total Environ., 575, 1582-1596, https://doi.org/10.1016/j.scitotenv.2016.10.081, 2017.

Wang, T., Dai, J., Lam, K. S., Nan Poon, C., and Brasseur, G. P.: Twenty-five years of lower tropospheric ozone observations in tropical East Asia: The influence of emissions and weather patterns, Geophys. Res. Lett., 46, 11463-11470, https://doi.org/10.1029/2019g1084459, 2019.

Wang, Y., Chen, Z., Wu, Q., Liang, H., Huang, L., Li, H., Lu, K., Wu, Y., Dong, H., Zeng, L., and Zhang, Y.: Observation of atmospheric peroxides during Wangdu Campaign 2014 at a rural site in the North China Plain, Atmos. Chem. Phys., 16, 10985-11000, https://doi.org/10.5194/acp-16-10985-2016, 2016.

Wang, Z., Wang, W., Tham, Y. J., Li, Q., Wang, H., Wen, L., Wang, X., and Wang, T.: Fast heterogeneous $\mathrm{N}_{2} \mathrm{O}_{5}$ uptake and $\mathrm{ClNO}_{2}$ production in power plant and industrial plumes observed in the nocturnal residual layer over the North China Plain, Atmos. Chem. Phys., 17, 12361-12378, https://doi.org/10.5194/acp-1712361-2017, 2017c.

Xing, J., Wang, S. X., Jang, C., Zhu, Y., and Hao, J. M.: Nonlinear response of ozone to precursor emission changes in China: a modeling study using response surface methodology, Atmos. Chem. Phys., 11, 5027-5044, https://doi.org/10.5194/acp-115027-2011, 2011.

Xing, J., Wang, J., Mathur, R., Wang, S., Sarwar, G., Pleim, J., Hogrefe, C., Zhang, Y., Jiang, J., Wong, D. C., and Hao, J.: Impacts of aerosol direct effects on tropospheric ozone through changes in atmospheric dynamics and photolysis rates, Atmos. Chem. Phys., 17, 9869-9883, https://doi.org/10.5194/acp-179869-2017, 2017.
Xu, X., Lin, W., Xu, W., Jin, J., Wang, Y., Zhang, G., Zhang, X., Ma, Z., Dong, Y., Ma, Q., Yu, D., Li, Z., Wang, D., and Zhao, H.: Long-term changes of regional ozone in China: Implications for human health and ecosystem impacts, Elem. Sci. Anth., 8, 13, https://doi.org/10.1525/elementa.409, 2020.

Xu, Z., Wang, T., Wu, J. Q., Xue, L. K., Chan, J., Zha, Q. Z., Zhou, S. Z., Louie, P. K. K., and Luk, C. W. Y.: Nitrous acid (HONO) in a polluted subtropical atmosphere: Seasonal variability, direct vehicle emissions and heterogeneous production at ground surface, Atmos. Environ., 106, 100-109, https://doi.org/10.1016/j.atmosenv.2015.01.061, 2015.

Yan, C., Tham, Y. J., Zha, Q. Z., Wang, X. F., Xue, L. K., Dai, J. N., Wang, Z., and Wang, T.: Fast heterogeneous loss of $\mathrm{N}_{2} \mathrm{O}_{5}$ leads to significant nighttime $\mathrm{NO}_{x}$ removal and nitrate aerosol formation at a coastal background environment of southern China, Sci. Total Environ., 677, 637-647, https://doi.org/10.1016/j.scitotenv.2019.04.389, 2019.

Yu, Y., Wang, Z., He, T., Meng, X., Xie, S., and Yu, H.: Driving factors of the significant increase in surface ozone in the Yangtze River Delta, China, during 2013-2017, Atmos. Pollut. Res., 10, 1357-1364, https://doi.org/10.1016/j.apr.2019.03.010, 2019.

Zhang, Q., Zheng, Y. X., Tong, D., Shao, M., Wang, S. X., Zhang, Y. H., Xu, X. D., Wang, J. N., He, H., Liu, W. Q., Ding, Y. H., Lei, Y., Li, J. H., Wang, Z. F., Zhang, X. Y., Wang, Y. S., Cheng, J., Liu, Y., Shi, Q. R., Yan, L., Geng, G. N., Hong, C. P., Li, M., Liu, F., Zheng, B., Cao, J. J., Ding, A. J., Gao, J., Fu, Q. Y., Huo, J. T., Liu, B. X., Liu, Z. R., Yang, F. M., He, K. B., and Hao, J. M.: Drivers of improved $\mathrm{PM}_{2.5}$ air quality in China from 2013 to 2017, P. Natl. Acad. Sci. USA, 116, 24463-24469, https://doi.org/10.1073/pnas.1907956116, 2019.

Zhang, Y. and Carmichael, G. R.: The role of mineral aerosol in tropospheric chemistry in East Asia - A model study, J. Appl. Meteorol., 38, 353-366, 1999.

Zheng, B., Tong, D., Li, M., Liu, F., Hong, C., Geng, G., Li, H., Li, X., Peng, L., Qi, J., Yan, L., Zhang, Y., Zhao, H., Zheng, Y., He, K., and Zhang, Q.: Trends in China's anthropogenic emissions since 2010 as the consequence of clean air actions, Atmos. Chem. Phys., 18, 14095-14111, https://doi.org/10.5194/acp-18-140952018, 2018.

Zhu, S., Butler, T., Sander, R., Ma, J., and Lawrence, M. G.: Impact of dust on tropospheric chemistry over polluted regions: a case study of the Beijing megacity, Atmos. Chem. Phys., 10, 38553873, https://doi.org/10.5194/acp-10-3855-2010, 2010. 